\title{
Drug-induced uveitis
}

\author{
Nikolas JS London', Sunir J Garg ${ }^{2^{*}}$, Ramana S Moorthy ${ }^{3,4}$ and Emmett T Cunningham Jr, 5
}

\begin{abstract}
A number of medications have been associated with uveitis. This review highlights both well-established and recently reported systemic, topical, intraocular, and vaccine-associated causes of drug-induced uveitis, and assigns a quantitative score to each medication based upon criteria originally described by Naranjo and associates.
\end{abstract}

\section{Review}

Introduction

Although most cases of uveitis are due to autoimmune disorders or infections, medications are recognized as an increasingly important cause of uveitis. A number of medications encompassing various forms of administration, including topical formulations, periocular and intraocular injections, and systemic medications, have been associated with uveitis. The recent availability of treatments for neovascular diseases of the retina and choroid with anti-vascular endothelial growth factor (anti-VEGF) agents has increased the prevalence and recognition of drug-induced uveitis. The mechanism(s) underlying drug-induced uveitis are generally unclear, although both inflammatory and toxic reactions have been suggested to play a role [1-3]. As such, for each agent summarized below, we only discuss the mechanism of drug-induced uveitis when specific studies have provided additional insight. This review highlights both wellestablished and recently reported systemic, topical, intraocular, and vaccine-associated causes of drug-induced uveitis. Although many drugs have been reported as causing uveitis, only those drugs with multiple independent publications to help confirm causation were further ranked. Using an algorithm originally proposed by Naranjo and associates, we quantitatively describe the association of various drugs to uveitis as 'definite, 'probable', 'possible', and 'doubtful' (Table 1) [4]. Naranjo scores of 9 or higher imply a definite association, scores of 5 to 8 a probable association, scores of 1 to 4 a possible association, and scores of 0 make an association

\footnotetext{
* Correspondence: sunirgarg@yahoo.com

${ }^{2}$ MidAtlantic Retina, The Retina Service of Wills Eye Institute, Thomas Jefferson University, 840 Walnut Street, Suite 1020, Philadelphia, PA 19107, USA

Full list of author information is available at the end of the article
}

doubtful. Table 2 lists the drugs most strongly associated with uveitis. Table 3 provides a list of those reviewed in the current paper and their likelihood of causing uveitis based on the Naranjo scoring system. In addition, the likelihood of causation per the Naranjo criteria is listed in parentheses next to the name of the medication in each subsection. Current updates regarding specific agents may be found at www.eyedrugregistry.com.

\section{Systemic medications}

\section{Cidofovir (Naranjo score 11, definite)}

Cidofovir is an infrequently administered antiviral medication initially utilized for the treatment of cytomegalovirus (CMV) retinitis in patients with profound immune suppression due to human immunodeficiency virus (HIV)/ acquired immune deficiency syndrome (AIDS). It selectively inhibits viral DNA polymerase, preventing virus replication. Cidofovir can be administered intravenously or directly into the vitreous cavity through an intravitreal injection. The efficacy of intravenous cidofovir for the treatment of previously untreated CMV retinitis in patients with HIV/AIDS has been demonstrated in a multicenter randomized trial and in a dose-ranging study of cidofovir in patients with HIV/AIDS and previously treated relapsing CMV retinitis $[5,6]$.

Compared to other treatments for CMV retinitis, cidofovir has several advantages, including a long intracellular half-life [7]. However, it is rarely used today due to several important side effects, the most serious of which is potentially irreversible nephrotoxicity. In addition, cidofovir has been shown to induce a non-granulomatous anterior uveitis in $17 \%$ to $89 \%$ of cases and hypotony in approximately $10 \%$ of cases [8-14]. These side effects occurred more frequently if patients received concomitant protease inhibitors, were previously treated for CMV retinitis, had chronic or recurrent retinitis, or had immune recovery [13]. Cidofovir- 
Table 1 The Naranjo scoresheet for assessing the association between a medication and an adverse reaction

\begin{tabular}{|c|c|c|c|c|}
\hline Question & Yes & No & Not known & Score \\
\hline 1. Are there previous conclusive reports on this reaction? & +1 & 0 & 0 & \\
\hline 2. Did the adverse event appear after the suspected drug was administered? & +2 & -1 & 0 & \\
\hline $\begin{array}{l}\text { 3. Did the adverse reaction improve when the drug was discontinued or a specific antagonist } \\
\text { was administered? }\end{array}$ & +1 & 0 & 0 & \\
\hline 4. Did the adverse reaction reappear when the drug was readministered? & +2 & -1 & 0 & \\
\hline $\begin{array}{l}\text { 5. Are there alternative causes (other than the drug) that could on their own have caused } \\
\text { the reaction? }\end{array}$ & -1 & +2 & 0 & \\
\hline 6. Did the reaction reappear when a placebo was given? & -1 & +1 & 0 & \\
\hline $\begin{array}{l}\text { 7. Was the drug detected in the blood (or other fluids) in concentrations } \\
\text { known to be toxic? }\end{array}$ & +1 & 0 & 0 & \\
\hline $\begin{array}{l}\text { 8. Was the reaction more severe when the dose was increased, or less severe } \\
\text { when the dose was decreased? }\end{array}$ & +1 & 0 & 0 & \\
\hline $\begin{array}{l}\text { 9. Did the patient have a similar reaction to the same or similar drugs in any } \\
\text { previous exposure? }\end{array}$ & +1 & 0 & 0 & \\
\hline 10. Was the adverse event confirmed by any objective evidence? & +1 & 0 & 0 & \\
\hline TOTAL & & & & \\
\hline
\end{tabular}

The maximal possible score is 13. Naranjo scores of 9 or higher imply a definite association, scores of 5 to 8 a probable association, scores of 1 to 4 a possible association, and scores of 0 make an association doubtful.

associated uveitis is more common following intravitreal administration and typically occurs after multiple injections, with a mean of 4.2 injections in one study [11]. Although nearly all cases of cidofovir-associated uveitis occur in the eyes with a history of active or treated CMV retinitis, there is one report in a patient with non-ocular CMV [15] and a second report of 5 of 14 patients treated with low-dose intravenous cidofovir for polyomavirus-associated nephropathy [16]. The incidence of ocular side effects decreases significantly with concomitant administration of oral probenecid, with one study reporting a decrease from $71 \%$ to $18 \%$ [8]. Probenecid is believed to inhibit intraocular secretion of cidofovir from the ciliary body, thereby minimizing its intraocular concentration [13]. Previously, the pathogenesis of cidofovir-associated uveitis was hypothesized to be due to a direct reaction with the CMV; however, uveitis has been associated with the use of cidofovir in nonCMV-related viral infections as well [16].

Treatment involves prompt initiation of a topical corticosteroid and a cycloplegic/mydriatic agent. Severe inflammation may require discontinuation of cidofovir [12], but this is not required in most cases. Hypotony is typically only seen in eyes with uveitis and may be associated with choroidal detachment, retinal detachment,

Table 2 Drugs associated with uveitis (modified from Cunningham et al. [2])

\begin{tabular}{|c|c|c|c|}
\hline Systemic & Topical & Intraocular & Vaccines \\
\hline TNF-a antagonists $^{a}$ & Prostaglandin analogs ${ }^{a}$ & Antibiotics $^{a}$ & Bacille Calmette-Guérin (BCG) $)^{a, c}$ \\
\hline Rifabutin ${ }^{a}$ & Metipranolol ${ }^{a}$ & Cidofovir $^{a}$ & Influenza ${ }^{a}$ \\
\hline Bisphosphonates $^{a}$ & Corticosteroids $^{a}$ & Urokinase $^{a}$ & Hepatitis $B^{a}$ \\
\hline Sulfonamides ${ }^{a}$ & Cholinomimetics $^{a}$ & Plasmin/microplasmin ${ }^{a}$ & Measles, mumps, and rubella (MMR) ${ }^{b}$ \\
\hline Diethylcarbamazine $^{a}$ & Brimonidine $^{a}$ & Antibodies (ranibizumab, bevacizumab, etc.) ${ }^{a}$ & Diphtheria, tetanus, and pertussis (DPT) ${ }^{\mathrm{b}}$ \\
\hline Fluoroquinolones $^{a}$ & Antibiotics $^{a}$ & Triamcinolone acetonide ${ }^{a}$ & Varicella ${ }^{b}$ \\
\hline Oral contraceptives ${ }^{b}$ & Betaxolol ${ }^{b}$ & & Smallpox \\
\hline Topiramate $^{b}$ & Cholinesterase inhibitors ${ }^{b}$ & & \\
\hline \multicolumn{4}{|l|}{ Trifluoperazine $^{b}$} \\
\hline \multicolumn{4}{|l|}{ Quinidine $^{b}$} \\
\hline \multicolumn{4}{|l|}{ Ibuprofen $^{\text {b }}$} \\
\hline \multicolumn{4}{|l|}{ Reserpine $^{b}$} \\
\hline \multicolumn{4}{|l|}{ Sildenafil $^{b}$} \\
\hline Clomiphene citrate $^{b}$ & & & \\
\hline
\end{tabular}

A comprehensive list of drugs reported to be associated with uveitis may be found at www.eyedrugregistry.com. ${ }^{\mathrm{a}}$ Strong evidence; ${ }^{\mathrm{b}}$ anecdotal evidence; ${ }^{\mathrm{c}} \mathrm{uveitis}$ also associated with skin placement of purified protein derivative. 
Table 3 Quantitative assessment of causation of drug-induced uveitis using Naranjo algorithm

\begin{tabular}{|c|c|c|c|c|c|c|c|c|c|c|c|c|c|}
\hline \multirow[t]{2}{*}{ Route } & \multirow[t]{2}{*}{ Drug } & \multicolumn{10}{|c|}{ Score per Naranjo criterion } & \multirow{2}{*}{$\begin{array}{l}\text { Total } \\
\text { score }\end{array}$} & \multirow{2}{*}{$\begin{array}{l}\text { Likelihood of } \\
\text { causation }\end{array}$} \\
\hline & & 1 & 2 & 3 & 4 & 5 & 6 & 7 & 8 & 9 & 10 & & \\
\hline \multirow[t]{7}{*}{ Systemic } & Cidofovir & 1 & 2 & 1 & 2 & 2 & 0 & 1 & 1 & 0 & 1 & 11 & Definite \\
\hline & Rifabutin & 1 & 2 & 1 & 2 & 2 & 0 & 0 & 1 & 0 & 1 & 10 & Definite \\
\hline & Bisphosphonates & 1 & 2 & 1 & 1 & 2 & 0 & 0 & 0 & 1 & 1 & 10 & Definite \\
\hline & Sulfonamides & 1 & 2 & 1 & 2 & 2 & 0 & 0 & 0 & 1 & 1 & 10 & Definite \\
\hline & TNF-a inhibitors & 1 & 2 & 1 & 2 & 0 & 0 & 0 & 0 & 0 & 1 & 7 & Probable \\
\hline & Fluoroquinolones & 1 & 2 & 1 & 0 & 0 & 0 & 0 & 0 & 1 & 1 & 6 & Probable \\
\hline & DEC & 1 & 2 & 1 & 0 & -1 & 1 & 0 & 0 & 0 & 1 & 5 & Probable \\
\hline \multirow[t]{4}{*}{ Topical } & Metipranolol & 1 & 2 & 1 & 2 & 2 & 0 & 0 & 1 & 0 & 1 & 10 & Definite \\
\hline & Glucocorticosteroids & 1 & 2 & 1 & 2 & 0 & 1 & 0 & 0 & 1 & 1 & 9 & Definite $^{a}$ \\
\hline & Brimonidine & 1 & 2 & 1 & 2 & 2 & 0 & 0 & 0 & 0 & 1 & 9 & Definite \\
\hline & Prostaglandin analogs & 1 & 2 & 1 & 2 & 2 & 0 & 0 & 0 & 0 & 1 & 9 & Definite \\
\hline \multirow[t]{3}{*}{ Intraocular } & Cidofovir & 1 & 2 & 1 & 2 & 2 & 0 & 1 & 1 & 0 & 1 & 11 & Definite \\
\hline & Anti-VEGF agents & 1 & 2 & 1 & 2 & 2 & 1 & 0 & 0 & 1 & 1 & 11 & Definite \\
\hline & Triamcinolone acetonide & 1 & 2 & 1 & 2 & -1 & 0 & 0 & 0 & 1 & 1 & 7 & Probable \\
\hline \multirow[t]{5}{*}{ Vaccines } & BCG & 1 & 2 & 1 & 2 & 2 & 0 & 0 & 0 & 0 & 1 & 9 & Definite \\
\hline & Influenza & 1 & 2 & 1 & 0 & 2 & 0 & 0 & 0 & 0 & 1 & 7 & Probable \\
\hline & MMR & 1 & 2 & 1 & 0 & 2 & 0 & 0 & 0 & 0 & 1 & 7 & Probable \\
\hline & Hepatitis B & 1 & 2 & 0 & 0 & 2 & 0 & 0 & 0 & 0 & 1 & 6 & Probable \\
\hline & Varicella & 1 & 2 & 1 & 0 & -1 & 0 & 0 & 0 & 0 & 1 & 4 & Possible \\
\hline
\end{tabular}

macular folds, or visual acuity reduction. In most of the reported cases, hypotony was treated with topical and/or periocular corticosteroids as well as avoidance of additional cidofovir injections when possible $[9,11,17]$. Visually significant hypotony occasionally can persist for an extended period of time $[11,17]$.

\section{Rifabutin (Naranjo score 10, definite)}

Rifabutin is an oral bacteriocidal antibiotic used as prophylaxis against Mycobacterium avium complex (MAC), typically for immunocompromised patients and particularly those infected by the HIV. It is most commonly associated with anterior uveitis with hypopyon (Figure 1), although intermediate uveitis, panuveitis, and retinal vasculitis have been reported $[18,19]$.

Most of our understanding of rifabutin-induced uveitis comes from cases series reported in the early- to mid1990s [20-23]. Saran and associates described the clinical features of seven patients with HIV/AIDS who received between 300 to $600 \mathrm{mg}$ of rifabutin daily along with clarithromycin and fluoconazole, and the majority of patients also received concomitant ethambutol. In this report, five patients presented with acute hypopyon uveitis 51 to 393 days (median 79 days) after starting the medications. All patients eventually developed bilateral anterior uveitis. Vision recovered to $20 / 30$ in all patients within 3 weeks of starting topical corticosteroid treatment alone, although three of the five patients required rifabutin dose reduction and/or discontinuation. In a larger group of 24 patients on $600 \mathrm{mg}$ of rifabutin per day along with clarithromycin and ethambutol, Shafran and colleagues described the development of ocular irritation and redness in $75 \%$ and $54 \%$ of patients, respectively, after a median of 42 days of rifabutin use. Photophobia occurred in $33 \%$ of patients, and a hypopyon developed in $29 \%$ of patients [24]. In the same study, patients who were on a lower dose of rifabutin $(300 \mathrm{mg} /$ day) seldom developed uveitis, and when it occurred, it took at least 7 months of medication use for the uveitis to develop. Skinner and Blaschke subsequently confirmed that drugrelated uveitis was unusual at the recommended dose of $300 \mathrm{mg} /$ day [25].

Risk factors for the development of rifabutin-associated uveitis include dosage and duration of rifabutin therapy, low body weight, and use of concomitant medications, including clarithromycin and ritonavir [21]. In a multivariate analysis of patients taking $600 \mathrm{mg}$ of rifabutin daily, Shafran and colleagues found that uveitis occurred in $64 \%$ of patients weighing less than $55 \mathrm{~kg}$, in $45 \%$ of patients 55 to $65 \mathrm{~kg}$, and in only $14 \%$ of patients weighing over $65 \mathrm{~kg}$ [24]. Several medications, such as clarithromycin and ritonavir, may exacerbate rifabutin-related side effects such as 


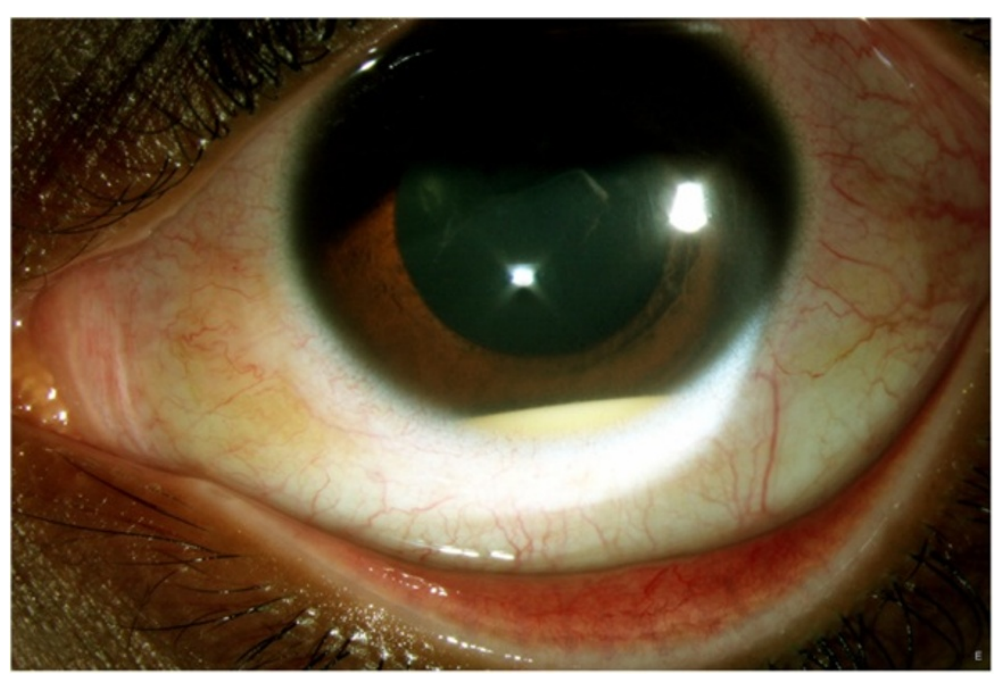

Figure 1 Slit-lamp photograph of hypopyon uveitis. A 17-year-old Eritrean girl who was on rifabutin for recurrent MAC prophylaxis developed anterior uveitis with a hypopyon. The patient also had retinal vasculitis. The inflammation completely resolved following cessation of rifabutin. Photograph courtesy of H. Nida Sen, MD, MHS (see [18]).

uveitis through inhibition of hepatic cytochrome P-450 [26-28]. Although systemic azoles, such as fluoconazole, also inhibit cytochrome P-450, Shafran and associates found no evidence that concurrent use of systemic azoles increased the risk of uveitis [21].

Rifabutin-induced uveitis likely results from direct rifabutin toxicity. The association between rifabutin and uveitis is supported by an association with dosage and with the duration of use, as well as bilateral involvement, limited rechallenge data [29], and reversibility with drug discontinuation.

\section{Bisphosphonates (Naranjo score 10, definite)}

Bisphosphonates are primarily used to treat osteoporosis and to prevent fractures due to malignant bone disease. While they are generally well tolerated [30], several medications in this class have been associated with uveitis. Moreover, bisphosphonates have been noted to cause scleritis/episcleritis in some patients [31].

Intravenous pamidronate sodium is the bisphosphonate most frequently associated with ocular side effects, and symptoms typically develop 1 to 6 days after starting treatment [32]. Conjunctivitis appears to be the most common ocular manifestation, followed by anterior uveitis and scleritis/episcleritis [31-37]. Among 23 cases reported by the Ciba-Geigy Central Epidemiology and Drug Safety Center in 1993, 13 (57\%) had non-specific conjunctivitis, 7 (30\%) had anterior uveitis (most commonly bilateral), and 3 (13\%) had unilateral episcleritis or scleritis [32]. The daily dose of pamidronate in this study ranged from 30 to 120 mg. A positive rechallenge reaction was noted in $11 / 15$ patients $(73 \%)$ in whom it was tested. Most patients with non-specific conjunctivitis recovered spontaneously within several days. In patients with anterior uveitis, the severity of inflammation ranged from minimal, resolving spontaneously within $24 \mathrm{~h}$, to severe and required topical corticosteroids with or without a cycloplegic agent and, occasionally, hospitalization. Episcleritis or scleritis was noted in three patients between 1 and 6 days following intravenous pamidronate disodium treatment. All patients recovered fully with treatment. The patient with episcleritis was treated with oral indomethacin, and the patient with posterior scleritis was treated with oral corticosteroids. The treatment for the patient with anterior scleritis was not elaborated upon beyond 'hospitalization.'

More recently, Fraunfelder and Fraunfelder reported 17 cases of unilateral scleritis associated with intravenous pamidronate with doses ranging from 30 to $60 \mathrm{mg}$ daily [38]. All of these cases required the discontinuation of pamidronate therapy for full resolution of the inflammation. Positive rechallenge data were provided for six of these cases.

Although less common, similar side effects have been observed with the oral agents alendronate [39-41], risedronate [42,43], etidronate [44], and intravenous zoledronic acid [45-47]. Although rechallenge data are not available, alendronate has been associated with scleritis and acute non-granulomatous anterior uveitis [40-42]. Only one case of risedronate-associated anterior uveitis has been reported [42].

Theories regarding the mechanism of bisphosphonateinduced uveitis include immunologic or toxic reactions caused by the release of inflammatory cytokines [31,48]. Nitrogen-containing bisphosphonates are known to cause 
a systemic acute phase reaction, including the development of transient influenza-like symptoms, in approximately $30 \%$ of patients following the first intravenous infusion [49]. It should be noted, however, that inflammatory reactions, including anterior uveitis, can occur following administration of non-nitrogen, halogen-containing bisphosphonates, such as clodronate [50]. Patients receiving bisphosphonates may also develop leukopenia as well as elevation of C-reactive protein, interleukin-1, and interleukin-6, all of which may contribute to the development of uveitis.

Treatment depends on the type and severity of the ocular inflammation. The conjunctivitis is typically self-limiting, although artificial tears and/or topical non-steroidal anti-inflammatory drugs may provide symptomatic relief. More substantial inflammation may require topical or systemic corticosteroid therapy. Either a change of drug to a non-nitrogen-containing bisphosphonate or cessation of bisphosphonates altogether should be considered in some cases of anterior uveitis and in nearly all cases of scleritis $[31,47,50]$.

\section{Sulfonamides (Naranjo score 10, definite)}

Sulfonamides are antibiotics used to treat a number of common infections, including urinary tract infections and toxoplasmosis. Newer sulfonamides are used as anticonvulsants, diuretics, and as dermatologic agents. Several reports have linked sulfonamide use with a mild non-granulomatous anterior uveitis [51,52].

The largest case series of sulfonamide-associated uveitis was reported by Tilden and associates in 1991 [51]. Using the data on 12 patients obtained from the $\mathrm{Na}$ tional Registry of Drug-Induced Ocular Side Effects, the US Food and Drug Administration, and two additional case reports, they described 14 patients who developed non-granulomatous anterior uveitis. Six (43\%) of the patients had bilateral involvement, and most developed symptoms within a week of drug initiation. Patients rechallenged with trimethoprim-sulfamethoxazole, a common sulfonamide, developed recurrent inflammation within $24 \mathrm{~h}$. Five patients also had evidence of other sulfonamide-induced side effects such as Stevens-Johnson syndrome (SIS), erythema multiforme, stomatitis, glossitis, vesicular rash, or abnormal liver function.

Often associated with sulfanomide use, SJS and toxic epidermal necrolysis are acute, severe, self-limited but potentially life-threatening drug reactions which may present with dermatologic findings such as widespread mucosal erosions with numerous erythematous macules and, eventually, epithelial detachment. Common ophthalmic manifestations of SIS include lid, conjunctival, and corneal inflammation and scarring, which may result in severe visual loss [53]. Uveitis is uncommon in SJS, but has been reported [54].
Non-sulfonamide medications, particularly trimethoprim, may play an under-appreciated role in some cases of presumed sulfonamide-induced uveitis. Notably, most of the reported cases involve trimethoprim-sulfamethoxazole. This includes at least 12 of the 14 patients in the original case series by Tilden and colleagues [51]. Several case reports have also implicated trimethoprim alone, including two with positive rechallenge data as described below [55-57].

Pathak and Power described a 41-year-old woman who developed bilateral non-granulomatous anterior uveitis 2 days after receiving $200 \mathrm{mg}$ of trimethoprim twice daily. Her work-up was unremarkable, and her inflammation promptly resolved with topical therapy and drug discontinuation, only to recur $45 \mathrm{~min}$ following rechallenge with $200 \mathrm{mg}$ of trimethoprim [55]. On two separate occasions, a 38-year-old woman developed flu-like symptoms as well as bilateral non-granulomatous anterior uveitis within days of starting trimethoprim-sulfamethoxazole [56]. She subsequently developed bilateral non-granulomatous anterior uveitis within a day of starting trimethoprim alone. All episodes resolved promptly with topical corticosteroid therapy [56].

\section{Tumor necrosis factor inhibitors (Naranjo score 7, probable)}

Tumor necrosis factor (TNF)- $\alpha$ is a proinflammatory cytokine strongly implicated in the pathogenesis of autoimmune disease. Inhibition of TNF- $\alpha$ is an effective therapy for treating a variety of inflammatory conditions, including rheumatoid arthritis, juvenile idiopathic arthritis, Crohn's disease, psoriatic arthritis, and ankylosing spondylitis. These agents have been used to treat ocular inflammation associated with these diseases as well as for the off label to treat both uveitis and scleritis [2,3,58-65]. The TNF- $\alpha$ inhibitors most commonly used for uveitis are infliximab, adalimumab, and less commonly etanercept. Infliximab is a chimeric mouse-human monoclonal antibody administered as an intravenous infusion. Adalimumab is a fully humanized monoclonal antibody administered subcutaneously. In contrast, etanercept is a genetically engineered soluble TNF receptor conjugated to the Fc region of human IgG immunoglobulin administered as a subcutaneous injection.

Anti-TNF therapies have been studied extensively since their introduction and have demonstrated generally acceptable safety profiles given the severity of the disorders they are intended to treat. Autoimmune reactions, specifically a lupus-like syndrome as well as autoimmune hepatitis, have been described with these agents. A recent report reviewed over 800 cases of new-onset autoimmune diseases occurring after the use of these medications to treat a range of diseases, including systemic disease such as systemic lupus erythematosus, organ-specific processes such as interstitial lung disease, and uveitis [66]. Most cases appeared within 1 to 12 months of starting 
therapy, and the large majority of cases completely resolved after discontinuing the medication. Of the cases reviewed, 87 involved paradoxical new intraocular inflammation after starting the medication. Even more striking, another subset of patients who developed intraocular inflammation was being treated for diseases not commonly associated with uveitis. The authors specifically described onset of intraocular inflammation after starting anti-TNF agents as one with a relatively poor outcome.

More recently, additional anecdotal reports and metaanalyses have implicated all three agents, particularly etanercept, as a cause of uveitis [66-75]. In 2007, Lim and colleagues reviewed all cases of uveitis associated with etanercept, infliximab, and adalimumab reported to national databases between 1998 and 2006, and excluded patients with underlying disease likely to be associated with uveitis [76]. In total, they found 59 cases thought to have drug-induced uveitis: 43 with etanercept, 14 with infliximab, and 2 with adalimumab. Etanercept was significantly more likely to be associated with uveitis than either infliximab (odds ratio 5.375) or adalimumab (odds ratio 8.6). There were also dechallenge/rechallenge data for a limited number of patients within the etanercept group, which strengthened the association of the drug with uveitis causation [76].

The anti-TNF agents, particularly etanercept, have also been noted to induce paradoxical, biopsy-proven sarcoidosis (or sarcoid-like granulomatosis), including ocular sarcoidosis (Figure 2) [2,77-81]. Affected patients had varied presentations. The onset of uveitis ranged from 3 weeks to 6 years and included anterior and/or posterior ocular inflammation as well as periphlebitis or chorioretinitis. Most patients recovered spontaneously once the offending agent was discontinued, but some required systemic corticosteroids.

The cause of paradoxical inflammation induced by anti-TNF agents is not clear. The inverse relationship between TNF- $\alpha$ and the pro-inflammatory cytokine interferon may promote immune cell activation, autoantibody formation, and immune complex deposition, eventually leading to the development of autoimmune disease $[2,82]$. It has also been suggested that TNF- $\alpha$ inhibition may promote infection by organisms associated with non-caseating granuloma formation [2]. The reason for the difference between the various TNF inhibitors and risk of developing uveitis is unknown, but it may reflect a differential alteration of the cytokine milieu and/ or differential effectiveness in treating intraocular inflammation [2].

\section{Oral fluoroquinolones (Naranjo score 6, probable)}

Uveitis associated with systemic fluoroquinolone therapy was first described in 2004 [83]. Since that time, at least 40 cases have been described, ranging from isolated case reports to a spontaneous large case series identified from reporting databases [70,83-87]. Of note, identical cases have been reported with no identified exposure to systemic fluoroquinolone therapy, suggesting that other factors might contribute [88]. Most of the commonly prescribed oral fluoroquinolones have been implicated, including ciprofloxacin, ofloxacin, gatifloxacin, levofloxacin, and norfloxacin. However, the most commonly implicated agent is moxifloxacin. In all cases, the medication was given at the standard oral dose. Uveitis developed a median of 13 days (range 0 to 20 days) after drug initiation. Patients presented with bilateral ocular pain and visual impairment. Examination often revealed fine, pigmented keratic precipitates with prominent pigment in the anterior chamber with only minimal non-pigmented cell (Figure 3). Another common feature included diffuse iris transillumination defects with atonic pupils (Figures 3 and 4). Up to $50 \%$ of patients developed ocular hypertension or glaucoma requiring intraocular pressure-lowering therapy - presumably related to drug-induced pigment dispersion $[86,87]$.

The pathophysiology of fluoroquinolone-associated uveitis is largely unknown but may involve phototoxicity, autoimmune predisposition, and/or concurrent viral infection. Phototoxicity has been proposed as a mechanism but is unlikely, given the restriction of the findings to the eyes as opposed to other sun-exposed areas [85]. There also may be a predisposition to autoimmune disorders. Of the 40 patients described by Hinkle and associates, 27 (69\%) were women, the median age was 54 years, and HLA-B27 and HLA-B51 haplotypes were identified in $20 \%$ and $40 \%$ of tested individuals, respectively [84]. Concurrent viral infection is another possibility but is unlikely to adequately account for the findings [84-86]. A single case report described a concave iris configuration leading to a potential mechanical explanation; however, this was not described in other cases [86]. Interestingly, this constellation of signs and symptoms has not been described with topical or intracameral injection of fluoroquinolones.

\section{Diethylacarbamazine (Naranjo score 5, probable)}

Diethylcarbamazine (DEC) is a powerful microfilaricide used to treat onchocerciasis. It was widely used prior to the introduction of ivermectin. Diethylcarbamazine causes death of the microfilaria, including those that are present within the eye, leading to an intense inflammatory reaction known as the Mazzotti reaction [89,90]. Anterior uveitis, transient retinal pigment epithelial lesions, chorioretinitis, and optic nerve inflammation have been described [91-93]. In a double-masked, placebo-controlled prospective trial, Taylor and associates showed ivermectin and DEC to have similar effectiveness at reducing intraocular microfilariae, with ivermectin inducing none of the ocular inflammatory 


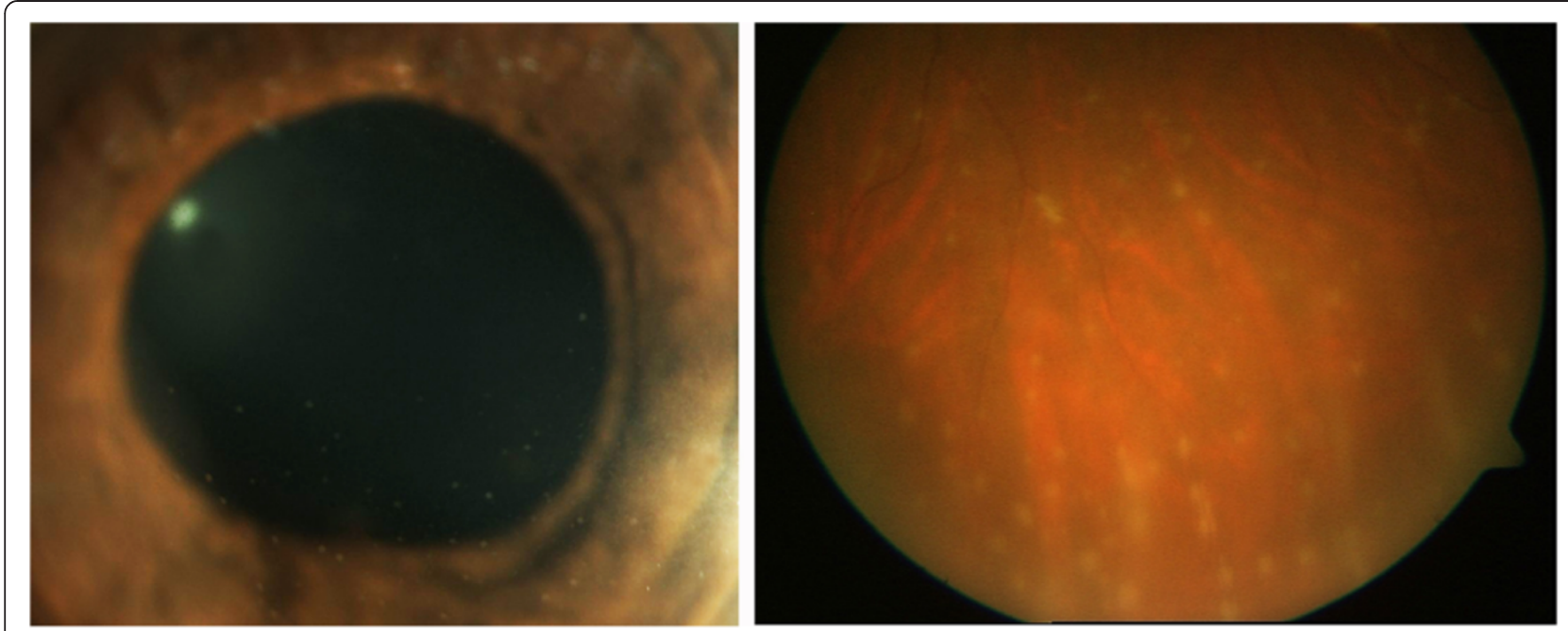

Figure 2 Slit-lamp (left) and fundus (right) photographs of a patient with etanercept-induced sarcoid-like uveitis. Showing keratic precipitates and mild vitreous inflammation with peripheral snowball vitreous opacities and patchy vasculitis. Photographs courtesy of Alex Fonollosa, MD (see [77]).

side effects [94]. Thus, the Mazzotti reaction alone is not enough to explain the uveitis associated with DEC. With limited data on rechallenge or dosing, DEC may be a possible cause of drug-induced uveitis.

\section{Topical medications}

\section{Metipranolol (Naranjo score 10, definite)}

Metipranolol is a non-selective topical beta-blocker used for the treatment of ocular hypertension and glaucoma. Shortly after its introduction, reports of associated granulomatous anterior uveitis began to appear [95-102]. Akingbehin and Villada presented the findings of 56 episodes of granulomatous anterior uveitis in 26 eyes of 15 patients [96]. Nearly all cases of uveitis occurred with the $0.6 \%$ dose compared to the $0.3 \%$ dose, leading to the withdrawal of the $0.6 \%$ dose from the market in 1990. Most cases developed after 7 to 31 months of therapy and patients typically presented with cell, flare, and granulomatous keratic precipitates, and $2 \%$ developed posterior synechiae. Over $50 \%$ of eyes also developed ocular hypertension. With discontinuation of metipranolol and initiation of topical corticosteroids, patients generally did quite well, with resolution of the inflammation after 3 to 5 weeks. In addition to a large number of case reports, positive rechallenge data confirm the association between metipranolol and the inflammation [103]. Initial hypotheses regarding the pathogenesis of metipranolol-induced uveitis centered around sterilization methods (i.e., gamma irradiation) used for multidose bottles; however, adverse reactions have been seen with single-dose bottles as well as with other sterilization methods $[98,100]$.

\section{Glucocorticosteroids (Naranjo score 9, definite)}

There are several reports of uveitis developing or worsening in otherwise non-inflamed eyes during or immediately following withdrawal of topical corticosteroids [104-106]. Although earlier reports mainly indicated dexamethasone sodium phosphate $0.1 \%$, corticosteroid withdrawal-associated uveitis has been described with different topical corticosteroid formulations, including prednisolone acetate $1 \%$ and dexamethasone $0.1 \%$ $[104,105,107]$.

The first report was published in 1970 [105]. In a prospective study of 2,000 patients designed to examine the effect of topical dexamethasone sodium phosphate $0.1 \%$ on intraocular pressure, the authors described two patients with no prior history of uveitis who developed anterior uveitis 2 to 5 days after discontinuing the medication [105]. An extensive uveitis work-up was unremarkable. The uveitis responded to intensive treatment with the same agent along with a cycloplegic/mydriatic medication. The largest report is a case series of $16 \mathrm{pa}-$ tients without a prior history of uveitis and without a history of predisposing systemic conditions, who developed anterior uveitis associated with the withdrawal of topical corticosteroids [104]. Fifteen of the cases (94\%) were associated with dexamethasone sodium phosphate $0.1 \%$, with the remaining case associated with triamcinolone acetonide $0.5 \%$ ointment. Inflammation developed in two of the patients while still using dexamethasone. Notably, the incidence of uveitis in black patients (14/ $261,5.4 \%)$ was significantly higher than the incidence in white patients $(2 / 360,0.5 \%)$. The significance of this is unclear and has not been confirmed in subsequent studies. An extensive uveitis work-up was unrevealing. In all 

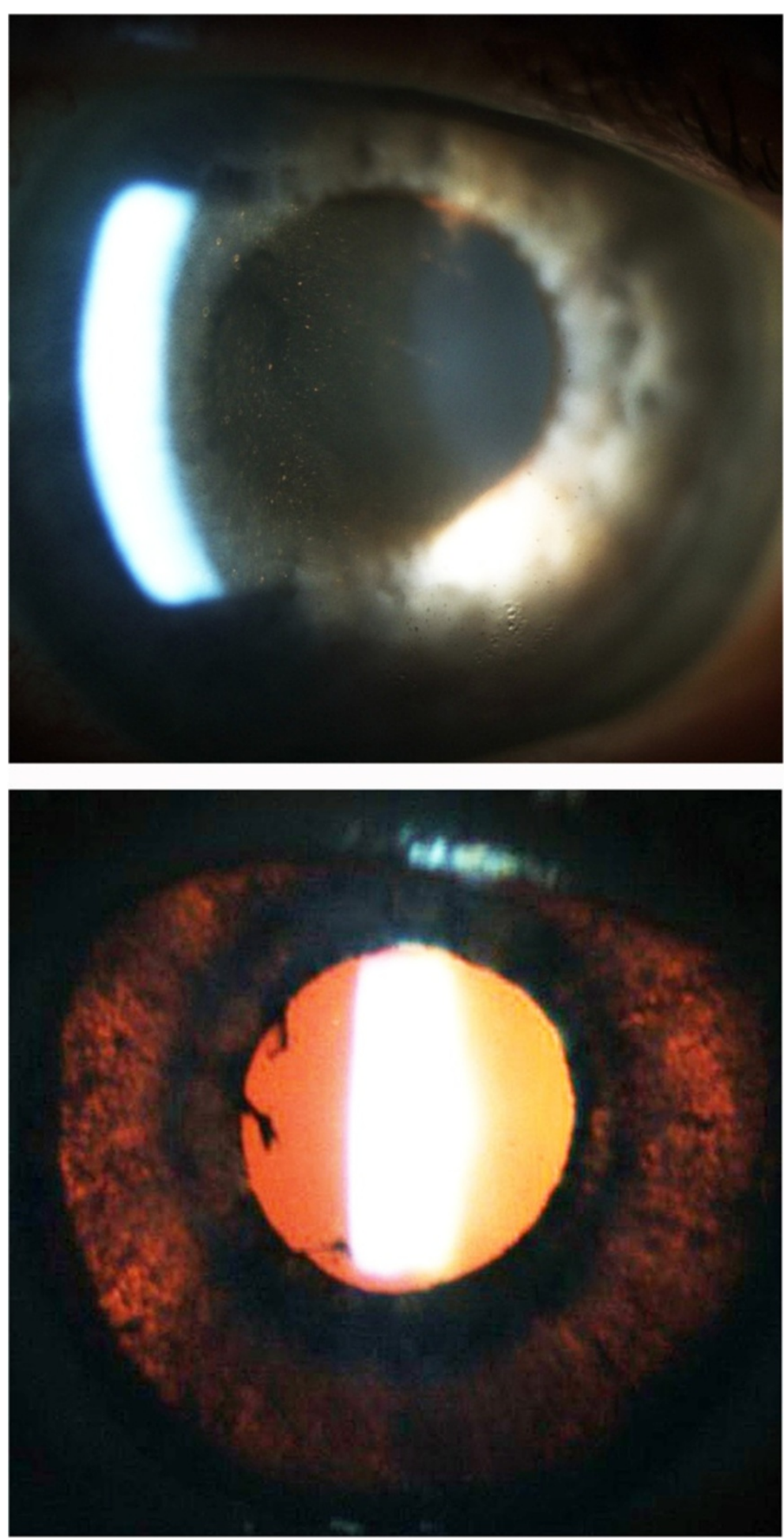

Figure 3 Slit-lamp photographs of the anterior chamber in a patient with moxifloxacin-associated uveitis. The patient presented with eye pain and redness 1 week following systemic moxifloxacin treatment. Examination revealed mixed pigment particles and inflammatory cells in the anterior chamber (top) and diffuse iris atrophy visualized on transillumination (bottom). Photographs courtesy of Sarkis H. Soukiasian, MD. 

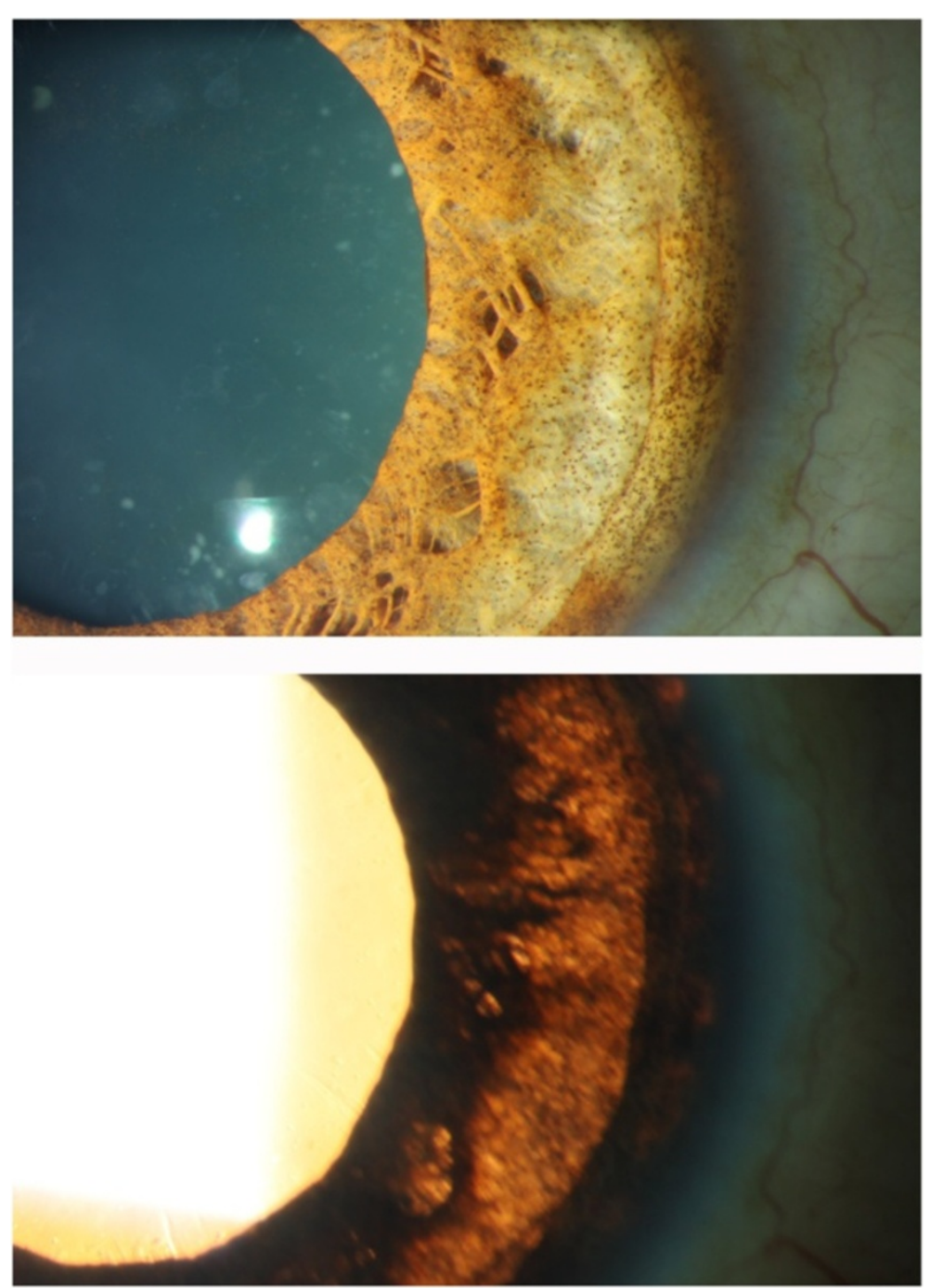

Figure 4 Anterior uveitis secondary to systemic moxifloxacin. Slit-lamp photographs of a patient who presented with eye redness and severe photophobia 3 weeks following oral moxifloxacin treatment for ear infection. Examination revealed mixed pigment particles and inflammatory cells in the anterior chamber, a dilated pupil with scattered pigment particles on the surface of the iris (top), and diffuse iris atrophy visualized on transillumination (bottom). Photographs courtesy of Ilknur Tugal-Tutkun, MD (see [88]).

cases, the inflammation resolved quickly with a topical cycloplegic/mydriatic agent alone. One patient was rechallenged with prednisolone acetate $1 \%$ for 10 days and developed recurrent uveitis 2 days after discontinuing the medication. Importantly, the medication vehicles alone failed to induce recurrent inflammation.

While the mechanism for corticosteroid-induced uveitis is unknown, its occurrence in patients with a positive fluorescent treponemal antibody absorption (FTA-ABS) serology has been noted [106]. Of note, there have been no new reports of corticosteroid-induced uveitis since 1979.

\section{Brimonidine (Naranjo score 9, definite)}

Brimonidine tartrate is a selective alpha2-adrenergic receptor agonist that is used for the treatment of glaucoma and ocular hypertension. In general, brimonidine is safe and well tolerated; however, there have been a small number of case reports describing granulomatous anterior uveitis with elevated intraocular pressure associated with chronic use [108-114]. In the majority of cases, patients were over the age of 75 and had used topical brimonidine for 11 months or longer. This is in contrast to brimonidine-induced allergic conjunctivitis, which typically occurs after 6 to 9 months of use. Byles and colleagues reported four patients who developed granulomatous anterior uveitis after using brimonidine for a mean of 14 months [108]. The inflammation only affected the treated and not the fellow eye, and resolved within a few weeks following drug discontinuation with or without a course of topical corticosteroids. Of note, 
all four patients developed recurrent inflammation within 3 weeks of restarting the medication.

Stopping the drug is the most effective treatment and usually results in rapid resolution of the inflammation. The use of topical corticosteroid therapy and a cycloplegic/mydriatic agent may be needed in some cases.

\section{Prostaglandin analogs (Naranjo score 9, definite)}

The topical prostaglandin analogs latanoprost, travoprost, and bimatoprost lower intraocular pressure primarily by increasing uveoscleral outflow [115-117]. These medications have been associated with several side effects, including conjunctival hyperemia, eyelash growth, iris and periocular skin pigmentation, iris cyst formation, cystoid macular edema, reactivation of herpes simplex keratitis, and anterior uveitis $[118,119]$.

While high levels of endogenous prostaglandins are known to cause intraocular inflammation and induce breakdown of the blood-aqueous barrier, the topical prostaglandin analogs were specifically designed to minimize potential prostaglandin-related side effects $[120,121]$. Despite this, several studies have described the development of anterior uveitis in a small percentage of patients. One study found the development of low-grade acute anterior uveitis in 8 of 163 eyes treated with latanoprost [122]. None of the patients had a previous history of uveitis or a medical condition potentially associated with uveitis. The inflammation developed after several months of latanoprost use in six of the eight eyes and after 1 day in both eyes of one patient [122]. The uveitis resolved promptly following discontinuation of the medication, although some eyes were also treated with a topical corticosteroid. In two of the three eyes tested, the inflammation recurred with rechallenge. Fechtner and associates presented positive dechallenge and rechallenge data of four patients with latanoprost-associated uveitis [123].

The mechanism by which prostaglandin analogs might cause anterior uveitis may involve the downstream stimulation of proinflammatory eicosanoids [123]. Moreover, prostaglandin analogs can increase IL-1 and IL-6 levels in the tears, and potentially in the aqueous humor, of treated patients [124].

Interestingly, when used in eyes with active endogenous anterior uveitis and ocular hypertension/glaucoma, topical prostaglandins do not appear to cause increased inflammation or cystoid macular edema when compared to other intraocular pressure (IOP)-lowering agents [125]. This may be in part due to the common use of concomitant topical, regional, or systemic corticosteroids in these patients that may blunt or mask the pro-inflammatory effect of the prostaglandin analogs.

\section{Intraocular medications}

\section{Cidofovir (Naranjo score 11, definite)}

In addition to systemic administration, intraocular injection of cidofovir has been associated with secondary inflammation. In phase I/II clinical trials, intravitreal cidofovir without concurrent systemic administration was associated with hypotony and a mild uveitis that was easily controlled with topical medications $[9,126]$. Other studies found a $26 \%$ incidence of mild to moderate non-granulomatous uveitis after intravitreal injection of cidofovir $[8,17]$. Similar to uveitis seen with systemic administration of cidofovir, the incidence of uveitis was substantially lower in patients who used concurrent systemic probenecid plus a topical corticosteroid [8,17]. In most cases, the hypotony was mild, with an IOP reduction from a mean baseline IOP of 9.3 to $7.4 \mathrm{mmHg} 2$ weeks after a 20- $\mu$ g intravitreal injection [126]. In one study, only 1 out of 24 eyes developed clinically significant hypotony (with an IOP of $1 \mathrm{mmHg}$ ) that was associated with choroidal detachment and decreased visual acuity [126]. This patient improved spontaneously.

\section{Anti-VEGF agents (Naranjo score 11, definite)}

Anti-VEGF agents are monoclonal antibodies (ranibizumab, bevacizumab), RNA aptamers (pegaptanib), or VEGF decoy receptors (afilbercept) that bind to and effectively inhibit the activity of VEGF. These agents are used for the treatment of a number of retinal disorders, including exudative age-related macular degeneration (AMD), diabetic macular edema, neovascular glaucoma, and macular edema associated with retinal vein occlusion (RVO) [127-143]. Despite an otherwise relatively strong safety profile in several large, multicenter studies, there have been several reports of uveitis associated with intraocular injection of these medications [130,144-153].

In 2004, pegaptanib sodium was the first anti-VEGF agent approved for the treatment of exudative age-related macular degeneration. It is an RNA-based aptamer that binds to VEGF-165 [154]. In a multicenter trial of 890 eyes treated with varying doses of pegaptanib, $14 \%$ of eyes developed some degree of anterior chamber inflammation compared to only $6 \%$ of eyes treated with a sham injection $(p=0.001)$ [154]. The authors attributed this relatively high incidence in both groups to the injection procedure and/or preparation. A follow-up study of 147 patients treated with doses up to $3 \mathrm{mg}$ (ten times higher than the approved dose) reported no cases of 'clinically relevant' ocular inflammation [155].

Ranibizumab has been studied more extensively than bevacizumab and afilbercept, with substantial data available regarding its safety profile. In the phase III ANCHOR and MARINA studies, severe inflammation (3+ or greater) occurred $2.9 \%$ and $2.1 \%$ of treated eyes, respectively, compared to $0 \%$ of control eyes, and $7.9 \%$ 
of treated eyes in the ANCHOR study developed some post-injection inflammation [128,133]. More recently, the CRUISE, BRAVO, PIER, and CATT studies reported ocular inflammation in $1 \%$ to $1.5 \%$ of treated eyes at some point during the study period $[129,131,133,134,140,156]$. However, in the BRAVO and CRUISE trials, inflammation occurred less frequently in ranibizumab-treated eyes than in sham-treated eyes [131,134]. The phase I/II FOCUS study, a study of ranibizumab plus PDT vs. PDT alone, reported a relatively high incidence of severe uveitis in $12.4 \%$ of eyes treated with ranibizumab plus PDT compared to $0 \%$ of patients who received PDT alone $[157,158]$. The authors attributed this difference to the formulation of ranibizumab used (lyophilized in the FOCUS study versus the Food and Drug Administration (FDA)-approved and commercially available liquid formulation) as well as the temporal relationship between ranibizumab injection and PDT treatment.

Bevacizumab appears to have a more variable rate of drug-associated inflammation. In a retrospective study of 2,000 injections ( 1,275 bevacizumab and 725 ranibizumab), Ladas and associates reported 38 instances of intraocular inflammation. This constituted $6 \%$ of treated eyes and 1.9\% of injections [147]. Most of the cases (30) were mild cases of anterior uveitis that presented within a few days after the injection and were easily controlled with topical corticosteroids. Eight cases (constituting 1.3\% of treated eyes and $0.4 \%$ of injections) presented within 1 to 3 weeks with moderate to severe inflammation. The inflammation in these cases was also easily controlled with a short course of topical and systemic corticosteroids. Only one eye experienced recurrent inflammation with each of three subsequent injections. More recently, the recent CATT study was a head-to-head comparison between ranibizumab and bevacizumab. The reported rates of inflammation in treated eyes were low at $0.3 \%$ for ranibizumab and $0.5 \%$ for bevacizumab $[129,130]$. Similarly, in a large, retrospective trial of 1,173 eyes treated with bevacizumab over 12 months, only 4 eyes $(0.3 \%$ of treated eyes, $0.09 \%$ of injections) developed severe uveitis [159]. All of these cases were managed with topical corticosteroids.

While most cases of uveitis following anti-VEGF injections are mild and transient, sporadic case series have described a severe inflammatory response, more commonly with bevacizumab compared to ranibizumab [146,149,160-162]. Sato and associates reported a series of five eyes that developed severe uveitis presenting as a toxic anterior segment syndrome following injection with bevacizumab all from the same lot [149]. Four of the five eyes had previously received intraocular bevacizumab without developing uveitis. The authors proposed that these cases were likely due to a toxic byproduct present in that lot of injections. In another series, Kay and colleagues described seven eyes of six patients that developed non-infectious uveitis from a cohort of 978 consecutive bevacizumab injections [161]. Of note, 338 ranibizumab injections were performed over the same time frame with no associated inflammation. Within $24 \mathrm{~h}$, all affected eyes developed signs and symptoms typical of anterior uveitis that rapidly improved with topical corticosteroid treatment. All eyes received bevacizumab from separate lots. Three eyes received subsequent injections and did not develop recurrent uveitis. Anterior chamber aspirate from one affected eye revealed evidence for foreign particulate matter, which the authors speculated might have been causally related.

Larger series appear to reflect the data from large trials, where special formulations (i.e., distinct from those commercially available) of the medications may be used. An internet-based survey of doctor-reported adverse events noted mild uveitis in $0.14 \%$ of eyes receiving bevacizumab injections [153]. In a retrospective review of 1,278 injections of bevacizumab, Wickremasinghe and associates reported that 14 cases $(1.1 \%)$ developed acute inflammation, but that study excluded those suspicious for endophthalmitis [163]. Most eyes had received prior injections (mean 2.7) and presented within 1 to 3 days with reduced vision and mild discomfort. Inflammation was mild (1 to $2+)$ in most cases, with equal inflammation present in both the anterior chamber and vitreous. All eyes responded well to intensive topical corticosteroid therapy. Shah and associates reported 16 cases of culture-negative endophthalmitis among 27,736 ranibizumab or bevacizumab injections, with no difference in incidence between the two medications [164]. Day and colleagues identified 6,154 patients receiving 40,903 anti-VEGF injections in the Medicare claims database and evaluated them for post-injection adverse outcomes compared to disease-matched controls [165]. At 2 years, uveitis was significantly more common in the antiVEGF group $(0.73 \%$ vs. $0.37 \%, p<0.01)$. The incidence of uveitis per injection was $0.11 \%$ in their series.

Aflibercept is a soluble decoy receptor fusion protein approved for the treatment of exudative AMD and macular edema associated with RVO. Early experience suggested that aflibercept may be less frequently associated with medication-related uveitis compared to ranibizumab or bevacizumab, affecting $0.6 \%$ of patients or fewer in the CLEAR-IT 2 and DA VINCI studies [137,139], with the COPERNICUS and EXCITE studies reporting zero cases $[138,166]$.

\section{Triamcinolone acetonide (Naranjo score 7, probable)}

Triamcinolone acetonide (TA) is a crystallized corticosteroid that can be injected into the eye. It is used to treat several posterior segment diseases, including noninfectious intermediate, posterior, and panuveitis, as well as various forms of macular edema [167-169]. Paradoxically, there have been reports of severe inflammation 
following intravitreal injection of TA [152,167,168,170-180], which is often called non-infectious or sterile endophthalmitis. Patients may present with reduced vision with little or no conjunctival injection or pain, but there may be substantial anterior chamber cell involvement, often with a hypopyon. Patients may also have moderate to significant vitritis. The incidence of this presumed inflammatory response is variable in the literature, occurring in $0.5 \%$ to $9.7 \%$ of injections $[170,172-175,178]$. In one study of 922 intravitreal (IV) TA injections [171], the authors reported presumed non-infectious endophthalmitis in eight eyes $(0.87 \%)$. Patients presented within 1 to 7 days of the injection with poor visual acuity and hypopyon. Treatment varied from systemic antibiotics to vitreous tap and injection of antibiotics to pars plana vitrectomy. None of the vitreous samples were culture positive, and the patients tended to do well, with an average final acuity of 20/75. Infectious endophthalmitis should be suspected in all patients with intraocular inflammation following IVTA, particularly those with worse conjunctival injection or pain, poorer vision, and/or involvement of the vitreous at presentation.

Some investigators have suggested that intraocular inflammation following IVTA may represent a toxic reaction to the drug, the vehicle, or a contaminant [172]. Jonas and colleagues administered 1,135 intravitreal injections of filtered $20 \mathrm{mg}$ TA and observed no cases of non-infectious endophthalmitis [181]. Given the high dose of TA, this argues against a direct toxic effect of drug. Supporting this hypothesis, one retrospective review of 646 injections of $4 \mathrm{mg}$ of TA noted significantly more cases of non-infectious endophthalmitis among patients who received TA with preservative than without [180]. Further support comes from two large studies that used a preservative-free, single-use formulation of IVTA in 457 patients with branch or central retinal vein occlusion. The authors reported no cases of post-injection inflammation $[167,168]$. Patients with a previous history of uveitis appear more likely to develop ocular inflammation after injection [182]. However, some authors found that a presumed non-infectious inflammatory reaction can occur even with preservative-free TA [179].

Another distinct entity that can be confused with infectious or non-infectious endophthalmitis is pseudoendophthalmitis due to the migration of the TA crystals into the anterior chamber, where they settle into a pseudohypopyon (Figure 5) [183]. Pseudo-endophthalmitis occurs less commonly in phakic patients and pseudophakic patients with an intact posterior capsule [170].

\section{Vaccines}

\section{Bacille Calmette-Guérin (Naranjo score 9, definite)}

Bacille Calmette-Guerin (BCG) is a vaccine used for prophylaxis against Mycobacterium tuberculosis and is frequently administered in countries with a high prevalence of infection. Bacille Calmette-Guerin vaccination is primarily used to prevent childhood tuberculous meningitis and miliary disease, and also has utility in the treatment of bladder cancer. Multiple case reports have implicated both BCG vaccination and intravesical BCG in the development of acute bilateral non-granulomatous or granulomatous anterior uveitis [184-192]. The inflammation may be associated with loss of iris pigmentation and typically responds within days to weeks to treatment with topical corticosteroids and a cycloplegic/mydriatic agent. Patients may also present with systemic symptoms resembling reactive arthritis [191-193]. Less commonly, patients may present with bilateral panuveitis [194,195], chorioretinitis [196], vitiligo [189], and/or optic neuritis [195].

Some authors have argued for an induced abnormal immune response due to molecular mimicry [184,185]. The authors of a case report of a 13-year-old girl who

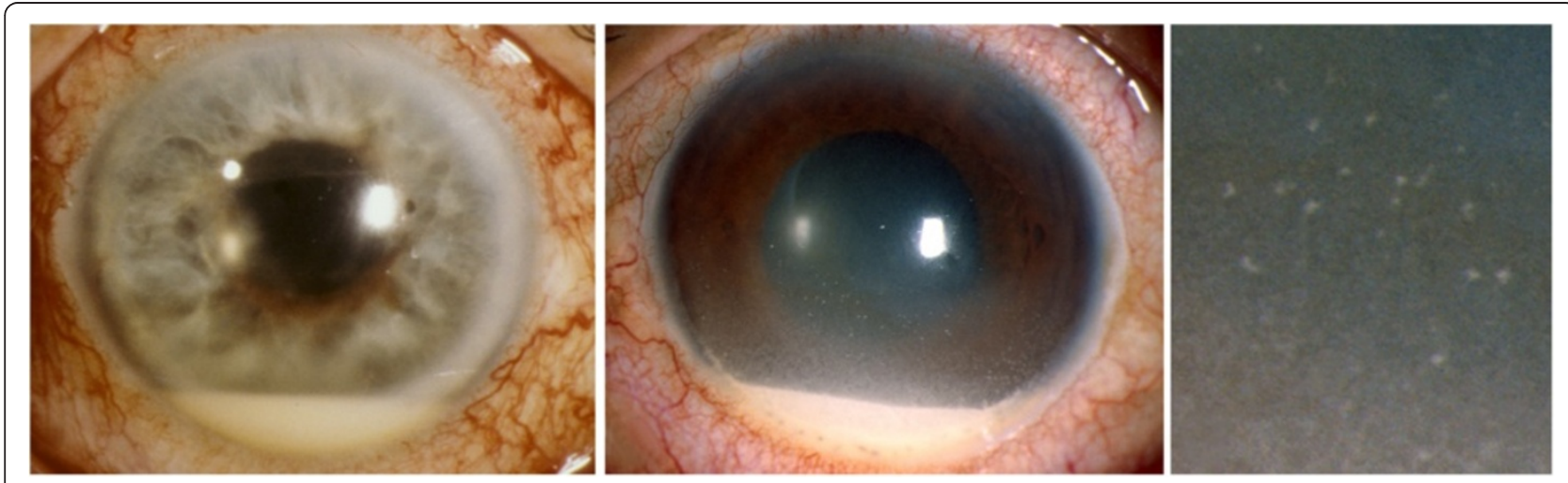

Figure 5 Early post-injection endophthalmitis (left) vs. pseudoendophthalmitis (center) following an intraocular injection of triamcinolone acetonide. Note the fibrinoid aqueous humor of endophthalmitis vs. the granular aqueous humor of pseudoendophthalmitis (right, higher magnification of the center showing granules). Center photograph courtesy of Andrew A. Moshfeghi, MD, MBA. Reproduced with permission from [183]. 
developed chronic bilateral anterior uveitis following BCG vaccination implicated her HLA-DR4 positivity, noting that HLA-DR4 is highly responsive to $M$. tuberculosis antigens [184]. A separate report described a 72-year-old woman who developed bilateral granulomatous anterior uveitis following intravesical BCG for bladder carcinoma [185]. The authors noted evidence for a polyclonal autoimmune reaction elicited by BCG as well as amino acid sequence homology between proteins from $M$. tuberculosis, BCG, and retinal antigens [185]. Of note, the patient was negative for HLA-B27 but positive for HLA-B8 and HLA-B38.

Several cases of uveitis following tuberculin skin testing (purified protein derivative or PPD) have been reported [197]. Reactions have ranged from panuveitis [197] to presentation resembling multifocal choroiditis and Vogt-Koyanagi-Harada disease with serous retinal detachment [198]. The delay in onset of uveitis following skin test placement supports an immune-mediated, delayedtype hypersensitivity reaction, perhaps to resident immune cells previously sensitized to M. tuberculosis [197].

\section{Measles, mumps, and rubella (Naranjo score 7, probable)}

Both anterior uveitis and panuveitis have been reported in association with measles, mumps, and rubella (MMR) vaccination in isolated case reports [199,200]. These reports have been sporadic, with variable severity. In two cases reported by Islam and associates, patients presented with bilateral panuveitis 4 and 6 weeks following MMR vaccination [199]. Both patients were HLA-B27 negative. Sedaghat and colleagues reported a 17-year-old girl who developed bilateral panuveitis associated with dermal vasculitis and arthritis shortly after MMR vaccination [200]. The inflammation may take 12 months or longer to resolve [199] and may require both topical and systemic corticosteroid treatment $[199,200]$. The mechanism may involve antigenic mimicry or processes involved in the preparation of the vaccine such as contamination or faulty preservation [199].

\section{Influenza (Naranjo score 7, probable)}

The influenza vaccination has been implicated in the development of secondary uveitis in several case reports, including bilateral panuveitis [201-204], recurrent panuveitis [205], and acute posterior multifocal placoid pigment epitheliopathy (APMPPE) [206]. Anterior uveitis can be controlled with topical corticosteroids and a cycloplegic/mydriatic agent, whereas posterior involvement may require systemic corticosteroids. Rothova and associates reported reactivation of acute retinal necrosis (ARN) following vaccination for the H1N1 strain of influenza [207].

\section{Hepatitis B (Naranjo score 6, probable)}

The hepatitis $B$ virus ( $\mathrm{HBV}$ ) vaccine is approved by the FDA for the prevention of hepatitis $B$ infection in children and for at-risk populations. A few case reports have implicated HBV vaccination in the development of uveitis, including a single case report of post-vaccination APMPPE [208-211]. The bulk of our information regarding hepatitis $B$ vaccine-related uveitis comes from a review of 32 cases reported to a national database [211]. In this series, the mean age of patients was 29 years ( 1 to 57 years), with a predominance of female patients ( 24 females vs. 8 males). The majority of cases developed within a few days following vaccination and more often after the initial vaccination than subsequent vaccinations, although several patients developed recurrent inflammation with each vaccination. A majority of patients (75\%) also reported a flu-like illness. It was hypothesized that this reaction represented either an immune-mediated delayed-type hypersensitivity reaction or a reaction to the vaccine carrier meant to potentiate the vaccine's immunogenic activity [211].

\section{Varicella (Naranjo score 4, possible)}

Several case reports describe the development of uveitis following varicella vaccination. Various presentations have been described, including isolated anterior uveitis [210], anterior uveitis associated with a vesicular rash [212], keratouveitis with inflammatory glaucoma and Hutchinson sign [213], sclerokeratitis with anterior uveitis (herpes zoster ophthalmicus) [214], and ARN [215]. In general, patients responded to standard treatment regimens, including topical corticosteroids and oral acyclovir. However, the two patients with ARN both required more aggressive treatment, including oral valacyclovir, intraocular ganciclovir or foscarnet, intravenous acyclovir, and eventually vitrectomy with silicone oil tamponade due to progressive disease [215]. Uveitis may occur due to reactivation of varicella virus or, alternatively, due to primary infection with the attenuated virus used in the vaccine.

\section{Conclusions}

Drug-induced uveitis is well-recognized and observed with a broad range of topical, systemic, and intraocular medications. A detailed drug history should be elicited, therefore, in all patients with otherwise unexplained uveitis. While drug-induced anterior uveitis typically responds to intensive topical corticosteroid and cycloplegic/ mydriatic therapy, medications suspected of causing uveitis may need to be decreased or discontinued when the inflammation is either severe or persistent. Formal criteria are available for grading the strength of evidence supporting causation in drug-induced uveitis and should be applied as new agents are studied. 


\section{Competing interests}

The authors declare that they have no competing interests.

\section{Authors' contributions}

NL drafted the manuscript. SG, RM, and EC provided guidance, and reviewed and edited the manuscript. All authors read and approved the final manuscript.

\section{Acknowledgments}

This work was supported in part by The Pacific Vision Foundation (ETC) and The San Francisco Retina Foundation (ETC).

\section{Author details}

1 Retina Consultants San Diego, 9850 Genesee Avenue, Suite 700, La Jolla, CA 92037, USA. ${ }^{2}$ MidAtlantic Retina, The Retina Service of Wills Eye Institute, Thomas Jefferson University, 840 Walnut Street, Suite 1020, Philadelphia, PA 19107, USA. ${ }^{3}$ Associated Vitreoretinal and Uveitis Consultants, St. Vincent Hospital and Health Services, Indianapolis, IN 46260, USA. ${ }^{4}$ Associate Clinical Professor of Ophthalmology, Indiana University School of Medicine, Indianapolis, IN 46202, USA. ${ }^{5}$ Department of Ophthalmology, California Pacific Medical Center, San Francisco, CA 94115, USA. ${ }^{6}$ Department of Ophthalmology, Stanford University School of Medicine, Stanford, CA 94305-5101, USA.

\section{Received: 4 February 2013 Accepted: 13 March 2013}

Published: 25 March 2013

\section{References}

1. Moorthy RS, Valluri S, Jampol LM (1998) Drug-induced uveitis. Surv Ophthalmol 42:557-570

2. Cunningham ET Jr, Pasadhika S, Suhler EB, Zierhut M (2012) Drug-induced inflammation in patients on TNFa inhibitors. Ocul Immunol Inflamm 20:2-5

3. Cunningham ET Jr, Zierhut M (2010) TNF inhibitors for uveitis: balancing efficacy and safety. Ocul Immunol Inflamm 18:421-423

4. Naranjo CA, Busto U, Sellers EM, Sandor P, Ruiz I, Roberts EA, Janecek E, Domecq C, Greenblatt DJ (1981) A method for estimating the probability of adverse drug reactions. Clin Pharmacol Ther 30:239-245

5. Lalezari JP, Drew WL, Glutzer E, James C, Miner D, Flaherty J, Fisher PE, Cundy K, Hannigan J, Martin JC, Jaffe HS (1995) (S)-1-[3-hydroxy-2(phosphonylmethoxy)propyl]cytosine (cidofovir): results of a phase I/II study of a novel antiviral nucleotide analogue. J Infect Dis 171:788-796

6. Lalezari JP (1997) Cidofovir: a new therapy for cytomegalovirus retinitis. J Acquir Immune Defic Syndr Hum Retrovirol 14(Suppl 1):S22-S26

7. Ho HT, Woods KL, Bronson JJ, De Boeck H, Martin JC, Hitchcock MJ (1992) Intracellular metabolism of the antiherpes agent (S)-1-[3-hydroxy-2(phosphonylmethoxy)propyl]cytosine. Mol Pharmacol 41:197-202

8. Chavez-de la Paz E, Arevalo JF, Kirsch LS, Munguia D, Rahhal FM, De Clerca E, Freeman WR (1997) Anterior nongranulomatous uveitis after intravitreal HPMPC (cidofovir) for the treatment of cytomegalovirus retinitis. Analysis and prevention. Ophthalmology 104:539-544

9. Kirsch LS, Arevalo JF, De Clercq E, Chavez de la Paz E, Munguia D, Garcia R, Freeman WR (1995) Phase I/II study of intravitreal cidofovir for the treatment of cytomegalovirus retinitis in patients with the acquired immunodeficiency syndrome. Am J Ophthalmol 119:466-476

10. Tseng AL, Mortimer CB, Salit IE (1999) Iritis associated with intravenous cidofovir. Ann Pharmacother 33:167-171

11. Davis JL, Taskintuna I, Freeman WR, Weinberg DV, Feuer WJ, Leonard RE (1997) Iritis and hypotony after treatment with intravenous cidofovir for cytomegalovirus retinitis. Arch Ophthalmol 115:733-737

12. Akler ME, Johnson DW, Burman WJ, Johnson SC (1998) Anterior uveitis and hypotony after intravenous cidofovir for the treatment of cytomegalovirus retinitis. Ophthalmology 105:651-657

13. Ambati J, Wynne KB, Angerame MC, Robinson MR (1999) Anterior uveitis associated with intravenous cidofovir use in patients with cytomegalovirus retinitis. Br J Ophthalmol 83:1153-1158

14. The Studies of Ocular Complications of AIDS Research Group in collaboration with the AIDS Clinical Trials Group (2000) Long-term follow-up of patients with AIDS treated with parenteral cidofovir for cytomegalovirus retinitis: the HPMPC peripheral cytomegalovirus retinitis trial. The studies of ocular complications of AIDS research group in collaboration with the AIDS clinical trials group. AIDS 14:1571-1581
15. Scott RA, Pavesio C (2000) Ocular side-effects from systemic HPMPC (Cidofovir) for a non-ocular cytomegalovirus infection. Am J Ophthalmol 130:126-127

16. Lopez V, Sola E, Gutierrez C, Burgos D, Cabello M, Garcia I, Florez P, Lopez J, Gonzalez-Molina M (2006) Anterior uveitis associated with treatment with intravenous cidofovir in kidney transplant patients with BK virus nephropathy. Transplant Proc 38:2412-2413

17. Rahhal FM, Arevalo JF, Munguia D, Taskintuna I, Chavez de la Paz E, Azen SP, Freeman WR (1996) Intravitreal cidofovir for the maintenance treatment of cytomegalovirus retinitis. Ophthalmology 103:1078-1083

18. Smith WM, Reddy MG, Hutcheson KA, Bishop RJ, Sen HN (2012) Rifabutinassociated hypopyon uveitis and retinal vasculitis with a history of acute myeloid leukemia. J Ophthalmic Inflamm Infect 2:149-152

19. Skolik S, Willermain F, Caspers LE (2005) Rifabutin-associated panuveitis with retinal vasculitis in pulmonary tuberculosis. Ocul Immunol Inflamm 13:483-485

20. Saran BR, Maguire AM, Nichols C, Frank I, Hertle RW, Brucker AJ, Goldman S, Brown M, Van Uitert B (1994) Hypopyon uveitis in patients with acquired immunodeficiency syndrome treated for systemic Mycobacterium avium complex infection with rifabutin. Arch Ophthalmol 112:1159-1165

21. Shafran SD, Deschenes J, Miller M, Phillips P, Toma E (1994) Uveitis and pseudojaundice during a regimen of clarithromycin, rifabutin, and ethambutol. MAC study group of the Canadian HIV trials network. N Engl J Med 330:438-439

22. Siegal FP, Eilbott D, Burger H, Gehan K, Davidson B, Kaell AT, Weiser B (1990) Dose-limiting toxicity of rifabutin in AIDS-related complex: syndrome of arthralgia/arthritis. AIDS 4:433-441

23. Frank MO, Graham MB, Wispelway B (1994) Rifabutin and uveitis. N Engl J Med 330:868

24. Shafran SD, Singer J, Zarowny DP, Deschenes J, Phillips P, Turgeon F, Aoki FY, Toma E, Miller M, Duperval R, Lemieux C, Schlech WF 3rd (1998) Determinants of rifabutin-associated uveitis in patients treated with rifabutin, clarithromycin, and ethambutol for Mycobacterium avium complex bacteremia: a multivariate analysis. Canadian HIV Trials Network Protocol 010 Study Group. J Infect Dis 177:252-255

25. Skinner MH, Blaschke TF (1995) Clinical pharmacokinetics of rifabutin. Clin Pharmacokinet 28:115-125

26. Kuper JI, D'Aprile M (2000) Drug-drug interactions of clinical significance in the treatment of patients with Mycobacterium avium complex disease. Clin Pharmacokinet 39:203-214

27. Cato A 3rd, Cavanaugh J, Shi H, Hsu A, Leonard J, Granneman R (1998) The effect of multiple doses of ritonavir on the pharmacokinetics of rifabutin. Clin Pharmacol Ther 63:414-421

28. Jacobs DS, Piliero PJ, Kuperwaser MG, Smith JA, Harris SD, Flanigan TP, Goldberg JH, Ives DV (1994) Acute uveitis associated with rifabutin use in patients with human immunodeficiency virus infection. Am J Ophthalmol 118:716-722

29. Schimkat M, Althaus C, Becker K, Sundmacher R (1996) Rifabutin-associated anterior uveitis in patients infected with human immunodeficiency virus. Ger J Ophthalmol 5:195-201

30. Watts NB (2003) Bisphosphonate treatment of osteoporosis. Clin Geriatr Med 19:395-414

31. Fraunfelder FW, Fraunfelder FT, Jensvold B (2003) Scleritis and other ocular side effects associated with pamidronate disodium. Am J Ophthalmol 135:219-222

32. Macarol V, Fraunfelder FT (1994) Pamidronate disodium and possible ocular adverse drug reactions. Am J Ophthalmol 118:220-224

33. Fraunfelder FW, Solomon J, Druker BJ, Esmaeli B, Kuyl J (2003) Ocular sideeffects associated with imatinib mesylate (Gleevec). J Ocul Pharmacol Ther 19:371-375

34. De S, Meyer P, Crisp AJ (1995) Pamidronate and uveitis. Br J Rheumatol $34: 479$

35. Stewart GO, Stuckey BG, Ward LC, Prince RL, Gutteridge DH, Constable IJ (1996) Iritis following intravenous pamidronate. Aust N Z J Med 26:414-415

36. Ghose K, Waterworth R, Trolove P, Highton J (1994) Uveitis associated with pamidronate. Aust N Z J Med 24:320

37. O'Donnell NP, Rao GP, Aguis-Fernandez A (1995) Paget's disease: ocular complications of disodium pamidronate treatment. Br J Clin Pract 49:272-273

38. Fraunfelder FW, Fraunfelder FT (2003) Bisphosphonates and ocular inflammation. N Engl J Med 348:1187-1188

39. Malik AR, Campbell SH, Toma NM (2002) Bilateral acute anterior uveitis after alendronate. Br J Ophthalmol 86:1443 
40. Mbekeani JN, Slamovits TL, Schwartz BH, Sauer HL (1999) Ocular inflammation associated with alendronate therapy. Arch Ophthalmol 117:837-838

41. Salmen S, Berrueta L, Sanchez N, Montes H, Borges L (2002) Nongranulomatous anterior uveitis associated with alendronate therapy. Invest Clin 43:49-52

42. Siris ES (1993) Bisphosphonates and iritis. Lancet 341:436-437

43. Tan YL, Sims J, Chee SP (2009) Bilateral uveitis secondary to bisphosphonate therapy. Ophthalmologica 223:215-216

44. Fraunfelder FW, Fraunfelder FT (2004) Adverse ocular drug reactions recently identified by the National Registry of Drug-Induced Ocular Side Effects. Ophthalmology 111:1275-1279

45. Moore MM, Beith JM (2008) Acute unilateral anterior uveitis and scleritis following a single infusion of zoledronate for metastatic breast cancer. Med J Aust 188:370-371

46. Banal F, Briot K, Ayoub G, Dougados M, Roux C (2008) Unilateral anterior uveitis complicating zoledronic acid therapy in prostate cancer. J Rheumatol 35:2458-2459

47. Benderson D, Karakunnel J, Kathuria S, Badros A (2006) Scleritis complicating zoledronic acid infusion. Clin Lymphoma Myeloma 7:145-147

48. Sharma NS, Ooi JL, Masselos K, Hooper MJ, Francis IC (2008) Zoledronic acid infusion and orbital inflammatory disease. N Engl J Med 359:1410-1411

49. Black DM, Delmas PD, Eastell R, Reid IR, Boonen S, Cauley JA, Cosman F, Lakatos P, Leung PC, Man Z, Mautalen C, Mesenbrink P, Hu H, Caminis J, Tong K, Rosario-Jansen T, Krasnow J, Hue TF, Sellmeyer D, Eriksen EF, Cummings SR (2007) Once-yearly zoledronic acid for treatment of postmenopausal osteoporosis. N Engl J Med 356:1809-1822

50. Fietta P, Manganelli P, Lodigiani L (2003) Clodronate induced uveitis. Ann Rheum Dis 62:378

51. Tilden ME, Rosenbaum JT, Fraunfelder FT (1991) Systemic sulfonamides as a cause of bilateral, anterior uveitis. Arch Ophthalmol 109:67-69

52. Northrop CV, Shepherd SM, Abbuhl S (1996) Sulfonamide-induced iritis. Am J Emerg Med 14:577-579

53. Power WJ, Ghoraishi M, Merayo-Lloves J, Neves RA, Foster CS (1995) Analysis of the acute ophthalmic manifestations of the erythema multiforme/Stevens-Johnson syndrome/toxic epidermal necrolysis disease spectrum. Ophthalmology 102:1669-1676

54. Arola O, Peltonen R, Rossi T (1998) Arthritis, uveitis, and Stevens-Johnson syndrome induced by trimethoprim. Lancet 351:1102

55. Pathak S, Power B (2007) Bilateral acute anterior uveitis as a side effect of trimethoprim. Eye (Lond) 21:252-253

56. Kristinsson JK, Hannesson OB, Sveinsson O, Thorleifsson H (1997) Bilateral anterior uveitis and retinal haemorrhages after administration of trimethoprim. Acta Ophthalmol Scand 75:314-315

57. Gilroy N, Gottlieb T, Spring P, Peiris O (1997) Trimethoprim-induced aseptic meningitis and uveitis. Lancet 350:112

58. Moreland LW, Baumgartner SW, Schiff MH, Tindall EA, Fleischmann RM, Weaver AL, Ettlinger RE, Cohen S, Koopman WJ, Mohler K, Widmer MB, Blosch CM (1997) Treatment of rheumatoid arthritis with a recombinant human tumor necrosis factor receptor (p75)-Fc fusion protein. N Engl J Med 337:141-147

59. Braun J, Brandt J, Listing J, Zink A, Alten R, Golder W, Gromnica-Ihle E, Kellner H, Krause A, Schneider M, Sorensen H, Zeidler H, Thriene W, Sieper J (2002) Treatment of active ankylosing spondylitis with infliximab: a randomised controlled multicentre trial. Lancet 359:1187-1193

60. Maini R, St Clair EW, Breedveld F, Furst D, Kalden J, Weisman M, Smolen J, Emery P, Harriman G, Feldmann M, Lipsky P (1999) Infliximab (chimeric antitumour necrosis factor alpha monoclonal antibody) versus placebo in rheumatoid arthritis patients receiving concomitant methotrexate: a randomised phase III trial. ATTRACT Study Group. Lancet 354:1932-1939

61. Chaudhari U, Romano P, Mulcahy LD, Dooley LT, Baker DG, Gottlieb AB (2001) Efficacy and safety of infliximab monotherapy for plaque-type psoriasis: a randomised trial. Lancet 357:1842-1847

62. Suhler EB, Smith JR, Wertheim MS, Lauer AK, Kurz DE, Pickard TD, Rosenbaum JT (2005) A prospective trial of infliximab therapy for refractory uveitis: preliminary safety and efficacy outcomes. Arch Ophthalmol 123:903-912

63. Murphy CC, Ayliffe WH, Booth A, Makanjuola D, Andrews PA, Jayne D (2004) Tumor necrosis factor alpha blockade with infliximab for refractory uveitis and scleritis. Ophthalmology 111:352-356

64. Murphy CC, Greiner K, Plskova J, Duncan L, Frost A, Isaacs JD, Rebello P, Waldmann H, Hale G, Forrester JV, Dick AD (2004) Neutralizing tumor necrosis factor activity leads to remission in patients with refractory noninfectious posterior uveitis. Arch Ophthalmol 122:845-851

65. Okada AA, Goto H, Ohno S, Mochizuki M (2012) Multicenter study of infliximab for refractory uveoretinitis in Behcet disease. Arch Ophthalmo 130:592-598

66. Ramos-Casals M, Roberto Perez A, Diaz-Lagares C, Cuadrado MJ, Khamashta MA (2010) Autoimmune diseases induced by biological agents: a doubleedged sword? Autoimmun Rev 9:188-193

67. Kakkassery V, Mergler S, Pleyer U (2010) Anti-TNF-alpha treatment: a possible promoter in endogenous uveitis? Observational report on six patients: occurrence of uveitis following etanercept treatment. Curr Eye Res 35:751-756

68. Gaujoux-Viala C, Giampietro C, Gaujoux T, Ea HK, Prati C, Orcel P, Wendling D, Liote F (2012) Scleritis: a paradoxical effect of etanercept? Etanerceptassociated inflammatory eye disease. J Rheumatol 39:233-239

69. Cobo-lbanez T, del Carmen OM, Munoz-Fernandez S, Madero-Prado R, Martin-Mola E (2008) Do TNF-blockers reduce or induce uveitis? Rheumatology (Oxford) 47:731-732

70. Wendling D, Paccou J, Berthelot JM, Flipo RM, Guillaume-Czitrom S, Prati C, Dernis E, Direz G, Ferrazzi V, Ristori JM (2011) New onset of uveitis during anti-tumor necrosis factor treatment for rheumatic diseases. Semin Arthritis Rheum 41:503-510

71. Reddy AR, Backhouse OC (2003) Does etanercept induce uveitis? Br J Ophthalmol 87:925

72. Hashkes PJ, Shajrawi I (2003) Sarcoid-related uveitis occurring during etanercept therapy. Clin Exp Rheumatol 21:645-646

73. Taban M, Dupps WJ, Mandell B, Perez VL (2006) Etanercept (enbrel)associated inflammatory eye disease: case report and review of the literature. Ocul Immunol Inflamm 14:145-150

74. Pontikaki I, Gerloni V, Gattinara M, Luriati A, Salmaso A, De Marco G, Teruzzi B, Valcamonica E, Fantini F (2006) Side effects of anti-TNFalpha therapy in juvenile idiopathic arthritis. Reumatismo 58:31-38

75. Monnet D, Moachon L, Dougados M, Brezin AP (2006) Severe uveitis in an HLA-B27-positive patient with ankylosing spondylitis. Nat Clin Pract Rheumatol 2:393-397

76. Lim LL, Fraunfelder FW, Rosenbaum JT (2007) Do tumor necrosis factor inhibitors cause uveitis? A registry-based study. Arthritis Rheum 56:3248-3252

77. Fonollosa A, Artaraz J, Les I, Martinez-Berriotxoa A, Izquierdo JP, Lopez AS, Gardeazaba J, Berasategui B, Martinez-Alday N (2012) Sarcoid intermediate uveitis following etanercept treatment: a case report and review of the literature. Ocul Immunol Inflamm 20(1):44-48

78. Seve P, Varron L, Broussolle C, Denis P, Kodjikian L (2012) Sarcoid-related uveitis occurring during adalimumab therapy. Ocul Immunol Inflamm 20:59-60

79. Daien Cl, Monnier A, Claudepierre P, Constantin A, Eschard JP, Houvenagel E, Samimi M, Pavy S, Pertuiset E, Toussirot E, Combe B, Morel J (2009) Sarcoid-like granulomatosis in patients treated with tumor necrosis factor blockers: 10 cases. Rheumatology (Oxford) 48:883-886

80. Toussirot E, Pertuiset E (2010) TNFalpha blocking agents and sarcoidosis: an update. Rev Med Interne 31:828-837

81. Massara A, Cavazzini L, La Corte R, Trotta F (2010) Sarcoidosis appearing during anti-tumor necrosis factor alpha therapy: a new "class effect" paradoxical phenomenon. Two case reports and literature review. Semin Arthritis Rheum 39:313-319

82. Viguier M, Richette P, Bachelez H, Wendling D, Aubin F (2009) Paradoxical adverse effects of anti-TNF-alpha treatment: onset or exacerbation of cutaneous disorders. Expert Rev Clin Immunol 5:421-431

83. Bringas Calvo R, Iglesias Cortinas D (2004) Acute and bilateral uveitis secondary to moxifloxacin. Arch Soc Esp Oftalmol 79:357-359

84. Hinkle DM, Dacey MS, Mandelcorn E, Kalyani P, Mauro J, Bates JH, Soukasian SH, Holland GN, Foster CS, Fraunfelder FT, Davis JL, Fraunfelder FW (2012) Bilateral uveitis associated with fluoroquinolone therapy. Cutan Ocul Toxicol 31:111-116

85. Wefers Bettink-Remeijer M, Brouwers K, van Langenhove L, De Waard PW, Missotten TO, Martinez Ciriano JP, Van Aken E (2009) Uveitis-like syndrome and iris transillumination after the use of oral moxifloxacin. Eye (Lond) 23:2260-2262

86. Willermain F, Deflorenne C, Bouffioux C, Janssens X, Koch P, Caspers L (2010) Uveitis-like syndrome and iris transillumination after the use of oral moxifloxacin. Eye (Lond) 24:1419

87. Tugal-Tutkun I, Araz B, Taskapili M, Akova YA, Yalniz-Akkaya Z, Berker N, Emre S, Gezer A (2009) Bilateral acute depigmentation of the iris: report of 
26 new cases and four-year follow-up of two patients. Ophthalmology 116:1552-1557, 1557.e1

88. Tugal-Tutkun I, Onal S, Garip A, Taskapili M, Kazokoglu H, Kadayifcilar S, Kestelyn P (2011) Bilateral acute iris transillumination. Arch Ophthalmol 129 (10):1312-1319

89. Mazzotti L (1948) Possibility of using the allergic reactions due to the administration of Hetrazan as an auxiliary diagnostic test for onchocerciasis in Mexico. Revista del Instituto de Salubridad y Enfermedades Tropicales 9:235-237 (in Spanish)

90. Francis H, Awadzi K, Ottesen EA (1985) The Mazzotti reaction following treatment of onchocerciasis with diethylcarbamazine: clinical severity as a function of infection intensity. Am J Trop Med Hyg 34:529-536

91. Greene BM, Taylor HR, Brown EJ, Humphrey RL, Lawley TJ (1983) Ocular and systemic complications of diethylcarbamazine therapy for onchocerciasis: association with circulating immune complexes. J Infect Dis 147:890-897

92. Bird AC, El-Sheikh H, Anderson J, Fuglsang H (1980) Changes in visual function and in the posterior segment of the eye during treatment of onchocerciasis with diethylcarbamazine citrate. Br J Ophthalmol 64:191-200

93. Taylor HR, Greene BM (1981) Ocular changes with oral and transepidermal diethylcarbamazine therapy of onchocerciasis. Br J Ophthalmol 65:494-502

94. Taylor HR, Murphy RP, Newland HS, White AT, D'Anna SA, Keyvan-Larijani E, Aziz MA, Cupp EW, Greene BM (1986) Treatment of onchocerciasis. The ocular effects of ivermectin and diethylcarbamazine. Arch Ophthalmol 104:863-870

95. Kinshuck D (1991) Glauline (metipranolol) induced uveitis and increase in intraocular pressure. Br J Ophthalmol 75:575

96. Akingbehin T, Villada JR (1991) Metipranolol-associated granulomatous anterior uveitis. Br J Ophthalmol 75:519-523

97. Beck RW, Moke P, Blair RC, Nissenbaum R (1996) Uveitis associated with topical beta-blockers. Arch Ophthalmol 114:1181-1182

98. O'Connor GR (1993) Granulomatous uveitis and metipranolol. Br J Ophthalmol 77:536-538

99. Watanabe TM, Hodes BL (1997) Bilateral anterior uveitis associated with a brand of metipranolol. Arch Ophthalmol 115:421-422

100. Kamalarajah S, Johnston PB (1999) Bilateral anterior uveitis associated with 0.3\% minims metipranolol. Eye (Lond) 13(Pt 3a):380-381

101. Melles RB, Wong IG (1994) Metipranolol-associated granulomatous iritis. Am J Ophthalmol 118:712-715

102. Schultz JS, Hoenig JA, Charles H (1993) Possible bilateral anterior uveitis secondary to metipranolol (optipranolol) therapy. Arch Ophthalmol 111:1606-1607

103. Akingbehin T, Villada JR, Walley T (1992) Metipranolol-induced adverse reactions: I. The rechallenge study. Eye (Lond) 6(Pt 3):277-279

104. Martins JC, Wilensky JT, Asseff CF, Obstbaum SA, Buerk KM (1974) Corticosteroid-induced uveitis. Am J Ophthalmol 77:433-437

105. Krupin T, LeBlanc RP, Becker B, Kolker AE, Podos SM (1970) Uveitis in association with topically administered corticosteroid. Am J Ophthalmol 70:883-885

106. Shin DH, Kass MA, Kolker AE, Becker B, Marr JJ, Bell EC (1976) Positive FTAABS tests in subjects with corticosteroid-induced uveitis. Am J Ophthalmol 82:259-260

107. Mindel JS, Goldberg J, Tavitian HO (1979) Similarity of the intraocular pressure response to different corticosteroid esters when compliance is controlled. Ophthalmology 86:99-107

108. Byles DB, Frith P, Salmon JF (2000) Anterior uveitis as a side effect of topical brimonidine. Am J Ophthalmol 130:287-291

109. Becker HI, Walton RC, Diamant JI, Zegans ME (2004) Anterior uveitis and concurrent allergic conjunctivitis associated with long-term use of topical 0.2\% brimonidine tartrate. Arch Ophthalmol 122:1063-1066

110. Nguyen EV, Azar D, Papalkar D, McCluskey P (2008) Brimonidine-induced anterior uveitis and conjunctivitis: clinical and histologic features. J Glaucoma 17:40-42

111. Cates CA, Jeffrey MN (2003) Granulomatous anterior uveitis associated with $0.2 \%$ topical brimonidine. Eye (Lond) 17:670-671

112. Goyal R, Ram AR (2000) Brimonidine tartarate $0.2 \%$ (Alphagan) associated granulomatous anterior uveitis. Eye (Lond) 14:908-910

113. Velasque L, Ducousso F, Pernod L, Vignal R, Deral V (2004) Anterior uveitis and topical brimonidine: a case report. J Fr Ophtalmol 27:1150-1152

114. Hondeghem K, Augustinus B, De Smet MD (2009) Bilateral granulomatous uveitis as a side effect of topical brimonidine: two case reports. Bull Soc Belge Ophtalmol 311:51-52
115. Camras CB (1996) Comparison of latanoprost and timolol in patients with ocular hypertension and glaucoma: a six-month masked, multicenter trial in the United States. The United States Latanoprost Study Group. Ophthalmology 103:138-147

116. Alm A, Stjernschantz J (1995) Effects on intraocular pressure and side effects of $0.005 \%$ Latanoprost applied once daily, evening or morning. A comparison with timolol. Scandinavian Latanoprost Study Group. Ophthalmology 102:1743-1752

117. Gabelt BT, Kaufman PL (1989) Prostaglandin F2 alpha increases uveoscleral outflow in the cynomolgus monkey. Exp Eye Res 49:389-402

118. Bito LZ (1997) Prostaglandins: a new approach to glaucoma management with a new, intriguing side effect. Surv Ophthalmol 41(Suppl 2):S1-S14

119. Grierson I, Jonsson M, Cracknell K (2004) Latanoprost and pigmentation. Jpn J Ophthalmol 48:602-612

120. Eakins KE (1977) Prostaglandin and non-prostaglandin mediated breeakdown of the blood-aqueous barrier. Exp Eye Res 25(Suppl):483-498

121. Unger WG (1989) Mediation of the ocular response to injury and irritation: peptides versus prostaglandins. Prog Clin Biol Res 312:293-328

122. Warwar RE, Bullock JD, Ballal D (1998) Cystoid macular edema and anterior uveitis associated with latanoprost use. Experience and incidence in a retrospective review of 94 patients. Ophthalmology 105:263-268

123. Fechtner RD, Khouri AS, Zimmerman TJ, Bullock J, Feldman R, Kulkarni P, Michael AJ, Realini T, Warwar R (1998) Anterior uveitis associated with latanoprost. Am J Ophthalmol 126:37-41

124. Lopilly Park HY, Kim JH, Lee KM, Park CK (2012) Effect of prostaglandin analogues on tear proteomics and expression of cytokines and matrix metalloproteinases in the conjunctiva and cornea. Exp Eye Res 94:13-21

125. Chang JH, McCluskey P, Missotten T, Ferrante P, Jalaludin B, Lightman S (2008) Use of ocular hypotensive prostaglandin analogues in patients with uveitis: does their use increase anterior uveitis and cystoid macular oedema? Br J Ophthalmol 92:916-921

126. Kirsch LS, Arevalo JF, Chavez De La Paz E, Munguia D, De Clercq E, Freeman WR (1995) Intravitreal cidofovir (HPMPC) treatment of cytomegalovirus retinitis in patients with acquired immune deficiency syndrome. Ophthalmology 102:533-542, discussion 42-43

127. Gheith ME, Siam GA, de Barros DS, Garg SJ, Moster MR (2007) Role of intravitreal bevacizumab in neovascular glaucoma. J Ocul Pharmacol Ther 23:487-491

128. Rosenfeld PJ, Brown DM, Heier JS, Boyer DS, Kaiser PK, Chung CY, Kim RY (2006) Ranibizumab for neovascular age-related macular degeneration. N Engl J Med 355:1419-1431

129. Martin DF, Maguire MG, Fine SL, Ying GS, Jaffe GJ, Grunwald JE, Toth C, Redford M, Ferris FL 3rd (2012) Ranibizumab and bevacizumab for treatment of neovascular age-related macular degeneration: two-year results. Ophthalmology 119:1388-1398

130. Martin DF, Maguire MG, Ying GS, Grunwald JE, Fine SL, Jaffe GJ (2011) Ranibizumab and bevacizumab for neovascular age-related macular degeneration. N Engl J Med 364:1897-1908

131. Campochiaro PA, Brown DM, Awh CC, Lee SY, Gray S, Saroj N, Murahash WY, Rubio RG (2011) Sustained benefits from ranibizumab for macular edema following central retinal vein occlusion: twelve-month outcomes of a phase III study. Ophthalmology 118:2041-2049

132. Brown DM, Campochiaro PA, Singh RP, Li Z, Gray S, Saroj N, Rundle AC, Rubio RG, Murahashi WY (2010) Ranibizumab for macular edema following central retinal vein occlusion: six-month primary end point results of a phase III study. Ophthalmology 117:1124-1133, e1

133. Brown DM, Michels M, Kaiser PK, Heier JS, Sy JP, lanchulev T (2009) Ranibizumab versus verteporfin photodynamic therapy for neovascular agerelated macular degeneration: two-year results of the ANCHOR study. Ophthalmology 116:57-65, e5

134. Brown DM, Campochiaro PA, Bhisitkul RB, Ho AC, Gray S, Saroj N, Adamis AP, Rubio RG, Murahashi WY (2011) Sustained benefits from ranibizumab for macular edema following branch retinal vein occlusion: 12-month outcomes of a phase III study. Ophthalmology 118:1594-1602

135. Campochiaro PA, Heier JS, Feiner L, Gray S, Saroj N, Rundle AC, Murahashi WY, Rubio RG (2010) Ranibizumab for macular edema following branch retinal vein occlusion: six-month primary end point results of a phase III study. Ophthalmology 117:1102-1112, e1

136. Brown DM, Kaiser PK, Michels M, Soubrane G, Heier JS, Kim RY, Sy JP, Schneider S (2006) Ranibizumab versus verteporfin for neovascular agerelated macular degeneration. N Engl J Med 355:1432-1444 
137. Heier JS, Boyer D, Nguyen QD, Marcus D, Roth DB, Yancopoulos G, Stahl N, Ingerman A, Vitti R, Berliner AJ, Yang K, Brown DM (2011) The 1-year results of CLEAR-IT 2, a phase 2 study of vascular endothelial growth factor trapeye dosed as-needed after 12-week fixed dosing. Ophthalmology 118:1098-1106

138. Boyer D, Heier J, Brown DM, Clark WL, Vitti R, Berliner AJ, Groetzbach G, Zeitz O, Sandbrink R, Zhu X, Beckmann K, Haller JA (2012) Vascular endothelial growth factor Trap-Eye for macular edema secondary to central retinal vein occlusion: six-month results of the phase 3 COPERNICUS study. Ophthalmology 119:1024-1032

139. Do DV, Schmidt-Erfurth U, Gonzalez VH, Gordon CM, Tolentino M, Berliner AJ, Vitti R, Ruckert R, Sandbrink R, Stein D, Yang K, Beckmann K, Heier JS (2011) The DA VINCI Study: phase 2 primary results of VEGF Trap-Eye in patients with diabetic macular edema. Ophthalmology 118:1819-1826

140. Regillo CD, Brown DM, Abraham P, Yue H, lanchulev T, Schneider S, Shams N (2008) Randomized, double-masked, sham-controlled trial of ranibizumab for neovascular age-related macular degeneration: PIER Study year 1. Am J Ophthalmol 145:239-248

141. Fung $A E$, Lalwani GA, Rosenfeld PJ, Dubovy SR, Michels S, Feuer WJ, Puliafito CA, Davis JL, Flynn HW Jr, Esquiabro M (2007) An optical coherence tomography-guided, variable dosing regimen with intravitreal ranibizumab (Lucentis) for neovascular age-related macular degeneration. Am J Ophthalmol 143:566-583

142. Massin P, Bandello F, Garweg JG, Hansen LL, Harding SP, Larsen M, Mitchell P, Sharp D, Wolf-Schnurrbusch UE, Gekkieva M, Weichselberger A, Wolf S (2010) Safety and efficacy of ranibizumab in diabetic macular edema (RESOLVE Study): a 12-month, randomized, controlled, double-masked, multicenter phase II study. Diabetes Care 33:2399-2405

143. Chakravarthy U, Adamis AP, Cunningham ET Jr, Goldbaum M, Guyer DR, Katz B, Patel M (2006) Year 2 efficacy results of 2 randomized controlled clinical trials of pegaptanib for neovascular age-related macular degeneration. Ophthalmology 113:1508, e1-25

144. Singerman LJ, Masonson H, Patel M, Adamis AP, Buggage R, Cunningham ET Jr, Goldbaum M, Katz B, Guyer D (2008) Pegaptanib sodium for neovascular age-related macular degeneration: third-year safety results of the VEGF Inhibition Study in Ocular Neovascularisation (VISION) trial. Br J Ophthalmol 92:1606-1611

145. Pieramici DJ, Avery RL, Castellarin AA, Nasir MA, Rabena M (2006) Case of anterior uveitis after intravitreal injection of bevacizumab. Retina 26:841-842

146. Bakri SJ, Larson TA, Edwards AO (2008) Intraocular inflammation following intravitreal injection of bevacizumab. Graefes Arch Clin Exp Ophthalmol 246:779-781

147. Ladas ID, Karagiannis DA, Rouvas AA, Kotsolis Al, Liotsou A, Vergados I (2009) Safety of repeat intravitreal injections of bevacizumab versus ranibizumab: our experience after 2,000 injections. Retina 29:313-318

148. Chong DY, Anand R, Williams PD, Qureshi JA, Callanan DG (2010) Characterization of sterile intraocular inflammatory responses after intravitreal bevacizumab injection. Retina 30:1432-1440

149. Sato T, Emi K, Ikeda T, Bando H, Sato S, Morita S, Oyagi T, Sawada K (2010) Severe intraocular inflammation after intravitreal injection of bevacizumab. Ophthalmology 117:512-516, 516e1-2

150. Yamashiro K, Tsujikawa A, Miyamoto K, Oh H, Otani A, Tamuara H, Ooto S, Sasahara M, Iwama D, Yoshimura N (2010) Sterile endophthalmitis after intravitreal injection of bevacizumab obtained from a single batch. Retina 30:485-490

151. Yenerel NM, Dinc UA, Gorgun E (2008) A case of sterile endophthalmitis after repeated intravitreal bevacizumab injection. J Ocul Pharmacol Ther 24:362-363

152. Jonas JB, Spandau UH, Rensch F, Von Baltz S, Schlichtenbrede F (2007) Infectious and noninfectious endophthalmitis after intravitreal bevacizumab. J Ocul Pharmacol Ther 23:240-242

153. Fung AE, Rosenfeld PJ, Reichel E (2006) The International Intravitreal Bevacizumab Safety Survey: using the internet to assess drug safety worldwide. Br J Ophthalmol 90:1344-1349

154. Gragoudas ES, Adamis AP, Cunningham ET Jr, Feinsod M, Guyer DR (2004) Pegaptanib for neovascular age-related macular degeneration. N Engl J Med 351:2805-2816

155. Apte RS, Modi M, Masonson H, Patel M, Whitfield L, Adamis AP (2007) Pegaptanib 1-year systemic safety results from a safety-pharmacokinetic trial in patients with neovascular age-related macular degeneration. Ophthalmology 114:1702-1712
156. Boyer DS, Heier JS, Brown DM, Francom SF, lanchulev T, Rubio RG (2009) A Phase IIlb study to evaluate the safety of ranibizumab in subjects with neovascular age-related macular degeneration. Ophthalmology 116:1731-1739

157. Antoszyk AN, Tuomi L, Chung CY, Singh A (2008) Ranibizumab combined with verteporfin photodynamic therapy in neovascular age-related macular degeneration (FOCUS): year 2 results. Am J Ophthalmol 145:862-874

158. Heier JS, Boyer DS, Ciulla TA, Ferrone PJ, Jumper JM, Gentile RC, Kotlovker D, Chung CY, Kim RY (2006) Ranibizumab combined with verteporfin photodynamic therapy in neovascular age-related macular degeneration: year 1 results of the FOCUS Study. Arch Ophthalmol 124:1532-1542

159. Wu L, Martinez-Castellanos MA, Quiroz-Mercado H, Arevalo JF, Berrocal MH, Farah ME, Maia M, Roca JA, Rodriguez FJ (2008) Twelve-month safety of intravitreal injections of bevacizumab (Avastin): results of the Pan-American Collaborative Retina Study Group (PACORES). Graefes Arch Clin Exp Ophthalmol 246:81-87

160. Antonopoulos C, Stem M, Comer GM (2011) Acute anterior uveitis following intravitreal bevacizumab but not subsequent ranibizumab. Clin Ophthalmol 5:1659-1662

161. Kay CN, Tarantola RM, Gehrs KM, Folk JC, Mahajan VB, Boldt HC, Syed NA, Russell SR (2011) Uveitis following intravitreal bevacizumab: a non-infectious cluster. Ophthalmic Surg Lasers Imaging 42:292-296

162. Georgopoulos M, Polak K, Prager F, Prunte C, Schmidt-Erfurth U (2009) Characteristics of severe intraocular inflammation following intravitreal injection of bevacizumab (Avastin). Br J Ophthalmol 93:457-462

163. Wickremasinghe SS, Michalova K, Gilhotra J, Guymer RH, Harper CA, Wong TY, Qureshi S (2008) Acute intraocular inflammation after intravitreous injections of bevacizumab for treatment of neovascular age-related macular degeneration. Ophthalmology 115:1911-1915

164. Shah CP, Garg SJ, Vander JF, Brown GC, Kaiser RS, Haller JA (2011) Outcomes and risk factors associated with endophthalmitis after intravitreal injection of anti-vascular endothelial growth factor agents. Ophthalmology 118:2028-2034

165. Day S, Acquah K, Mruthyunjaya P, Grossman DS, Lee PP, Sloan FA (2011) Ocular complications after anti-vascular endothelial growth factor therapy in Medicare patients with age-related macular degeneration. Am J Ophthalmol 152:266-272

166. Schmidt-Erfurth U, Eldem B, Guymer R, Korobelnik JF, Schlingemann RO, Axer-Siegel R, Wiedemann P, Simader C, Gekkieva M, Weichselberger A (2011) Efficacy and safety of monthly versus quarterly ranibizumab treatment in neovascular age-related macular degeneration: the EXCITE study. Ophthalmology 118:831-839

167. Scott IU, Ip MS, VanVeldhuisen PC, Oden NL, Blodi BA, Fisher M, Chan CK, Gonzalez VH, Singerman LJ, Tolentino M (2009) A randomized trial comparing the efficacy and safety of intravitreal triamcinolone with standard care to treat vision loss associated with macular edema secondary to branch retinal vein occlusion: the Standard Care vs Corticosteroid for Retinal Vein Occlusion (SCORE) study report 6. Arch Ophthalmol 127:1115-1128

168. Ip MS, Scott IU, VanVeldhuisen PC, Oden NL, Blodi BA, Fisher M, Singerman LJ, Tolentino M, Chan CK, Gonzalez VH (2009) A randomized trial comparing the efficacy and safety of intravitreal triamcinolone with observation to treat vision loss associated with macular edema secondary to central retinal vein occlusion: the Standard Care vs Corticosteroid for Retinal Vein Occlusion (SCORE) study report 5. Arch Ophthalmol 127:1101-1114

169. Diabetic Retinopathy Clinical Research Network (2008) A randomized trial comparing intravitreal triamcinolone acetonide and focal/grid photocoagulation for diabetic macular edema. Ophthalmology 115:14471449, 1449.e1-10

170. Wang LC, Yang CM (2005) Sterile endophthalmitis following intravitreal injection of triamcinolone acetonide. Ocul Immunol Inflamm 13:295-300

171. Moshfeghi DM, Kaiser PK, Bakri SJ, Kaiser RS, Maturi RK, Sears JE, Scott IU, Belmont J, Beer PM, Quiroz-Mercado H, Mieler WF (2005) Presumed sterile endophthalmitis following intravitreal triamcinolone acetonide injection. Ophthalmic Surg Lasers Imaging 36:24-29

172. Roth DB, Chieh J, Spirn MJ, Green SN, Yarian DL, Chaudhry NA (2003) Noninfectious endophthalmitis associated with intravitreal triamcinolone injection. Arch Ophthalmol 121:1279-1282

173. Nelson ML, Tennant MT, Sivalingam A, Regillo CD, Belmont JB, Martidis A (2003) Infectious and presumed noninfectious endophthalmitis after intravitreal triamcinolone acetonide injection. Retina 23:686-691

174. Ozkiris A, Erkilic K (2005) Complications of intravitreal injection of triamcinolone acetonide. Can J Ophthalmol 40:63-68 
175. Jonisch J, Lai JC, Deramo VA, Flug AJ, Fastenberg DM (2008) Increased incidence of sterile endophthalmitis following intravitreal preserved triamcinolone acetonide. Br J Ophthalmol 92:1051-1054

176. Simon S, Gray T, Dhanapala M, Gilhotra J (2010) Pseudohypopyon following intravitreal triamcinolone acetonide injection in a phakic eye. Clin Experiment Ophthalmol 38:76-77

177. Sharma MC, Lai WW, Shapiro MJ (2004) Pseudohypopyon following intravitreal triamcinolone acetonide injection. Cornea 23:398-399

178. Moshfeghi AA, Scott IU, Flynn HW Jr, Puliafito CA (2004) Pseudohypopyon after intravitreal triamcinolone acetonide injection for cystoid macular edema. Am J Ophthalmol 138:489-492

179. Lam A, Garg SJ, Spirn MJ, Fineman M, Sivalingam A (2008) Sterile endophthalmitis following intravitreal injection of preservative-free triamcinolone acetonide. Retinal Cases and Brief Reports 2:228-230

180. Maia M, Farah ME, Belfort RN, Penha FM, Lima Filho AA, Aggio FB, Jr Belfort $R$ (2007) Effects of intravitreal triamcinolone acetonide injection with and without preservative. $\mathrm{Br} J$ Ophthalmol 91:1122-1124

181. Jonas JB, Kreissig I, Spandau UH, Harder B (2006) Infectious and noninfectious endophthalmitis after intravitreal high-dosage triamcinolone acetonide. Am J Ophthalmol 141:579-580

182. Taban M, Singh RP, Chung JY, Lowder CY, Perez VL, Kaiser PK (2007) Sterile endophthalmitis after intravitreal triamcinolone: a possible association with uveitis. Am J Ophthalmol 144:50-54

183. Salz D, Prenner J, Cunningham ETJ (2010) Local complications of IV antiVEGF therapy. Review of Ophthalmology 17:66-75

184. Spratt A, Key T, Vivian AJ (2008) Chronic anterior uveitis following bacille Calmette-Guerin vaccination: molecular mimicry in action? J Pediatr Ophthalmol Strabismus 45:252-253

185. Garip A, Diedrichs-Mohring M, Thurau SR, Deeg CA, Wildner G (2009) Uveitis in a patient treated with Bacille-Calmette-Guerin: possible antigenic mimicry of mycobacterial and retinal antigens. Ophthalmology 116:2457-2462, e1-2

186. Morton DL, Eilber FR, Holmes EC, Hunt JS, Ketcham AS, Silverstein MJ, Sparks FC (1974) BCG immunotherapy of malignant melanoma: summary of a seven-year experience. Ann Surg 180:635-643

187. Pancaldi P, Van Linthoudt D, Alborino D, Haefliger JM, Ott H (1993) Reiter's syndrome after intravesical Bacillus Calmette-Guerin treatment for superficial bladder carcinoma. Br J Rheumatol 32:1096-1098

188. Faus S, Martinez Montauti JM, Puig L (1993) Reiter's syndrome after administration of intravesical bacille Calmette-Guerin. Clin Infect Dis 17:526-527

189. Donaldson RC, Canaan SA Jr, McLean RB, Ackerman LV (1974) Uveitis and vitiligo associated with BCG treatment for malignant melanoma. Surgery 76:771-778

190. Wertheim M, Astbury N (2002) Bilateral uveitis after intravesical BCG immunotherapy for bladder carcinoma. Br J Ophthalmol 86:706

191. Chevrel G, Zech C, Miossec P (1999) Severe uveitis followed by reactive arthritis after bacillus Calmette-Guerin therapy. J Rheumatol 26:1011

192. Price GE (1994) Arthritis and iritis after BCG therapy for bladder cancer. J Rheumatol 21:564-565

193. Missioux D, Hermabessiere J, Sauvezie B (2010) Arthritis and iritis after bacillus Calmette-Guerin therapy. J Rheumatol 1995:22

194. Jacob M, Gambrelle J, Fleury J, Durieu I, Kodjikian L, Duquesne N, Grange JD (2006) Panuveitis following intravesical bacille Calmette-Guerin therapy. J Fr Ophtalmol 29:552-555

195. Hegde V, Dean F (2005) Bilateral panuveitis and optic neuritis following Bacillus Calmette-Guerin (BCG) vaccination. Acta Paediatr 94:635-636

196. Guex-Crosier Y, Chamot L, Zografos L (2003) Chorioretinitis induced by intravesical Bacillus Calmette-Guerin (BCG) instillations for urinary bladder carcinoma. Klin Monbl Augenheilkd 220:193-195

197. Lish A, Berman DH (1993) Tuberculin-triggered panuveitis in a patient recently treated for active pulmonary tuberculosis. Am J Ophthalmol 116:771-773

198. Nussenblatt RB, Palestine AG (1989) Uveitis Fundamentals and Practice. Yearbook Medical Publishers, Chicago

199. Islam SM, El-Sheikh HF, Tabbara KF (2000) Anterior uveitis following combined vaccination for measles, mumps and rubella (MMR): a report of two cases. Acta Ophthalmol Scand 78:590-592

200. Sedaghat M, Zarei-Ghanavati S, Shokoohi S, Ghasemi A (2007) Panuveitis and dermal vasculitis following MMR vaccination. East Mediterr Health J 13:470-474
201. Blumberg S, Bienfang D, Kantrowitz FG (1980) A possible association between influenza vaccination and small-vessel vasculitis. Arch Intern Med 140:847-848

202. Thurairajan G, Hope-Ross MW, Situnayake RD, Murray PI (1997) Polyarthropathy, orbital myositis and posterior scleritis: an unusual adverse reaction to influenza vaccine. $\mathrm{Br} J$ Rheumatol 36:120-123

203. Wells MB, Garg S (2009) Bilateral panuveitis after influenza vaccination. Retinal Cases and Brief Reports 3:386-387

204. Blanche P, Decrette C, Sicard D (1994) Development of uveitis following vaccination for influenza. Clin Infect Dis 19:979

205. Knopf HL (1991) Recurrent uveitis after influenza vaccination. Ann Ophthalmol 23:213-214

206. Mendrinos E, Baglivo E (2010) Acute posterior multifocal placoid pigment epitheliopathy following influenza vaccination. Eye (Lond) 24:180-181

207. Rothova A, de Groot JD, Mudrikova T (2011) Reactivation of acute retinal necrosis after flu H1N1 vaccination. Br J Ophthalmol 95:291

208. Brezin AP, Massin-Korobelnik P, Boudin M, Gaudric A, LeHoang P (1995) Acute posterior multifocal placoid pigment epitheliopathy after hepatitis $B$ vaccine. Arch Ophthalmol 113:297-300

209. Fried M, Conen D, Conzelmann M, Steinemann E (1987) Uveitis after hepatitis B vaccination. Lancet 2:631-632

210. Islam SM, Tabbara KF (2002) Causes of uveitis at The Eye Center in Saudi Arabia: a retrospective review. Ophthalmic Epidemiol 9:239-249

211. Fraunfelder FW, Suhler EB, Fraunfelder FT (2010) Hepatitis B vaccine and uveitis: an emerging hypothesis suggested by review of 32 case reports. Cutan Ocul Toxicol 29:26-29

212. Esmaeli-Gutstein B, Winkelman JZ (1999) Uveitis associated with varicella virus vaccine. Am J Ophthalmol 127:733-734

213. Lin P, Yoon MK, Chiu CS (2009) Herpes zoster keratouveitis and inflammatory ocular hypertension 8 years after varicella vaccination. Ocul Immunol Inflamm 17:33-35

214. Naseri A, Good W, Cunningham ET Jr (2003) Herpes zoster virus sclerokeratitis and anterior uveitis in a child following varicella vaccination. Am J Ophthalmol 135:415-417

215. Charkoudian LD, Kaiser GM, Steinmetz RL, Srivastava SK (2011) Acute retina necrosis after herpes zoster vaccination. Arch Ophthalmol 129:1495-1497

doi:10.1186/1869-5760-3-43

Cite this article as: London et al: Drug-induced uveitis. Journal of Ophthalmic Inflammation and Infection 2013 3:43.

\section{Submit your manuscript to a SpringerOpen ${ }^{\odot}$ journal and benefit from:}

- Convenient online submission

- Rigorous peer review

- Immediate publication on acceptance

- Open access: articles freely available online

- High visibility within the field

- Retaining the copyright to your article

Submit your next manuscript at $>$ springeropen.com 